This is an Accepted Manuscript of an article published by Taylor \& Francis in Journal of Environmental Science and Health, Part A on 2020, available online: http://www.tandfonline.com/ with DOI https://doi.org/10.1080/10934529.2020.1852011 .

\title{
Modeling of the effect of zeolite concentration on the biological nitrification process in the presence of sulfide and organic matter
}

\author{
Lidersi Acosta-Corderoํㅜ, Fabio Carrera-Chapela ${ }^{2}$, Silvio Montalvo ${ }^{1}$, Lorna Guerrero ${ }^{3}$, \\ Nicolás Palominos ${ }^{1}$, Rafael Borja $^{4}$ and Cesar Huiliñir ${ }^{1 *}$ \\ ${ }^{1}$ Departamento de Ingeniería Química, Universidad de Santiago de Chile, Santiago, Chile \\ ${ }^{2}$ Escuela de Ingeniería Bioquímica, Pontificia Universidad Católica de Valparaíso. Avenida \\ Brasil 2085, Valparaíso, Chile. \\ ${ }^{3}$ Departamento de Ingeniería Química y Ambiental, Universidad Técnica Federico Santa \\ María, Valparaíso, Chile. \\ ${ }^{4}$ Instituto de la Grasa (CSIC), Campus Universitario Pablo de Olavide - Edificio 46, Ctra. \\ de Utrera, Km. 1, 41013 Sevilla, Spain.
}

\begin{abstract}
The evaluation of the nitrification kinetics in the simultaneous presence of sulfide and organic matter using zeolite as improver was the main goal of this work. According to the sensitivity and collinearity analyses, five parameters were the most sensitive in the model, whose calibrated values were: $\mu_{\max , A O B}=0.02642 \pm 0.002 \mathrm{~h}^{-1} ; \mu_{\max , N O B}=0.3307 \pm 0.416 \mathrm{~h}^{-1}$; $K_{S, N O B}=1.65 \cdot 10^{-6} \pm 2.85 \cdot 10^{-6} \mathrm{mgHNO}_{2}-\mathrm{N} / \mathrm{L} ; k_{S 2}=0.8213 \pm 0.076$, and $n=0.6537 \pm 0.030$.
\end{abstract}


*Address correspondence to Cesar Huiliñir, Departamento de Ingeniería Química, Universidad de Santiago de Chile, Santiago, Chile; Phone: (56)(2) 27181814; Fax: (56) (02) 6817135; E-mail: cesar.huilinir@usach.cl

A good fit between the experimental data and the model's results including the effect of zeolite on the kinetic parameters was obtained, with Theil inequality coefficient values between 0.109 and 0.007 for all the variables studied, with all of these values lower than 0.3. Thus, the model proposed is robust and can simulate the nitrification process in the presence of sulfide and organic matter when zeolite was used as improver.

KEYWORDS: kinetic parameters, modeling, nitrification kinetics, zeolite.

\section{Nomenclature}

\begin{tabular}{|c|c|}
\hline$c_{T A N}$ & : Total ammonia nitrogen concentration $\mathrm{NH}_{3}-\mathrm{N}+\mathrm{NH}_{4}{ }^{+}-\mathrm{N}, \mathrm{mg} \mathrm{N} \mathrm{L}^{-1}$ \\
\hline$c_{\mathrm{NO}_{2}^{-}}$ & : Total nitrite nitrogen concentration $\mathrm{HNO}_{2}-\mathrm{N}+\mathrm{NO}_{2}^{-}-\mathrm{N}, \mathrm{mg} \mathrm{N} \mathrm{L}^{-1}$ \\
\hline$c_{\mathrm{NO}_{3}^{-}}$ & : Total nitrate nitrogen concentration $\mathrm{HNO}_{3}-\mathrm{N}+\mathrm{NO}_{3}^{-}-\mathrm{N}, \mathrm{mg} \mathrm{N} \mathrm{L}^{-1}$ \\
\hline$c_{N_{3}}$ & : Concentration of $\mathrm{NH}_{3}-\mathrm{N}, \mathrm{mg} \mathrm{N} \mathrm{L}^{-1}$ \\
\hline$c_{\mathrm{HNO}_{2}}$ & : Concentration of $\mathrm{HNO}_{2}-\mathrm{N}, \mathrm{mg} \mathrm{N} \mathrm{L}^{-1}$ \\
\hline$c_{D O}$ & : Concentration of dissolved oxygen, $\mathrm{mg} \mathrm{O}_{2} \mathrm{~L}^{-1}$ \\
\hline$c_{H 2 S}$ & : Concentration of sulfide, $\mathrm{mg} \mathrm{S} \mathrm{L}^{-1}$ \\
\hline$c_{C O D}$ & : Concentration of organic matter as chemical oxygen demand (COD), $\mathrm{mg} \mathrm{L}^{-1}$ : \\
\hline$x_{A O B}$ & : Concentration of ammonia-oxidizing bacteria (AOB), mg VSS L-1 \\
\hline$x_{N O B}$ & : Concentration of nitrite-oxidizing bacteria (NOB), mg VSS L-1 \\
\hline$x_{H}$ & : Concentration of heterotrophic bacteria (HB), mg VSS L-1 \\
\hline$k_{d}$ & : Constant of death for nitrifying bacteria, $\mathrm{h}^{-1}$ \\
\hline$\mu_{\max , i}$ & : Maximum specific growth rate of $i: A O B, N O B, H B, \mathrm{~h}^{-1}$ \\
\hline$\mu_{i}$ & : Specific growth rate of $i: A O B, N O B, H B, \mathrm{~h}^{-1}$ \\
\hline$K_{s, A O B}$ & : Saturation constant for ammonia-oxidizers, $\mathrm{mg} \mathrm{NH}_{3}-\mathrm{N} \mathrm{L}^{-1}$ \\
\hline$K_{s, N O B}$ & : Saturation constant for nitrite-oxidizers, $\mathrm{mg} \mathrm{HNO} 2-\mathrm{N} \mathrm{L}^{-1}$ \\
\hline$K_{S, C O D}$ & : Saturation constant for chemical oxygen demand, mg COD L ${ }^{-1}$ \\
\hline
\end{tabular}




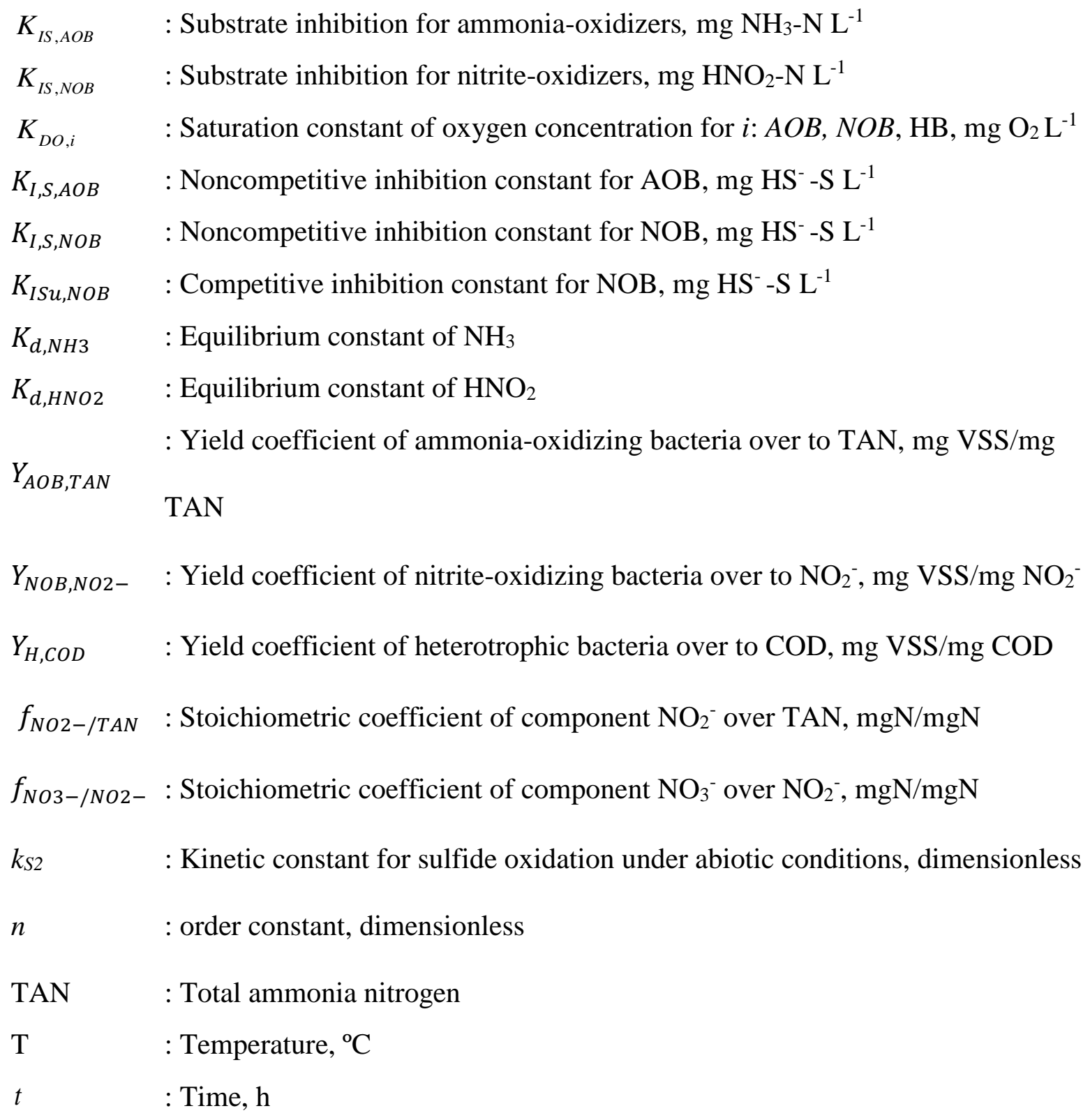

\section{Introduction}

Nitrification is a well-known biological process for oxidizing ammonia coming from industrial and municipal wastewaters. It is a two-step reaction: first, the ammonium is oxidized to nitrite by ammonium-oxidizing bacteria (AOB), and then nitrite is oxidized to nitrate by nitrite-oxidizing bacteria (NOB). ${ }^{[1-3]}$ These processes are sensitive to inhibitors, including sulfide and organic matter. ${ }^{[4]}$ Such compounds are present in many kinds of wastewaters together with ammonia; however, there are few studies of the nitrification 
processes in the presence of both sulfide and organic matter simultaneously, those studies basically using organic matter coming from petrochemical wastewater. ${ }^{[5,6]}$ On the other hand, the kinetics of nitrification in the simultaneous presence of sulfide and organic has not been proposed up to date. There are studies which reported the single effect of sulfide on nitrification ${ }^{[7-9]}$ and also several studies about nitrification in the presence of organic matter. $[10,11]$ However, the evaluation of a kinetic model involving the simultaneous effects of sulfide and organic matter has not been proposed and has never been reported in the literature. Therefore, the evaluation of nitrification kinetics in the presence of sulfide and organic matter simultaneously is one of the main goals of this work.

Nitrification inhibition due to the presence of both organic matter and sulfide could be avoided with the use of improvers of the process. "Improvers can reduce the effect of inhibition of some compounds on biological processes either by acting as a direct antagonist [12] or by delaying the effect of inhibition and helping the system to recover after being inhibited. They can also cause the system to increase resistance to toxicity from these compounds or decrease the time required to stabilize the systems. For instance, Chen et al. ${ }^{[12]}$ indicated that nickel can be used for decreasing the inhibition caused by cadmium and copper in anaerobic digestion processes and that sodium $\left(\mathrm{Na}^{+}\right)$, calcium $\left(\mathrm{Ca}^{2+}\right)$ and magnesium $\left(\mathrm{Mg}^{2+}\right)$ can be used as antagonists of ammonium inhibition of the anaerobic digestion process. In the case of nitrification, Young et al. ${ }^{[13]}$ used activated carbon improvers for nitrification in order to decreases the inhibition by phenol and free cyanide on the nitrification process. In this sense, zeolite is another improver that has been used in many biological processes such as: anaerobic digestion, nitrification, heterotrophic autotrophic denitrification ${ }^{[14-19]}$. In these processes, the use of zeolite improves the biological performance based on its ability to retain ammonia and form biofilm, in addition to its high porosity and large specific surface area ${ }^{[20]}$. Zeolite has the ability to adsorb molecules with a cross-sectional diameter 
suitable for its pore size, which have small diameters (3 to $10 \AA$ ) and are capable of exchanging their cations without significantly changing their structure ${ }^{[21]}$."

Recently, Huiliñir et al. ${ }^{[4]}$ proposed the use of natural zeolite for improving nitrification in discontinuous systems in the presence of sulfide and organic matter. Zeolite is a crystalline, hydrated aluminosilicate of alkali and alkaline earth cations, consisting of three-dimensionalframeworks of $\mathrm{SiO}_{4}{ }^{4-}$ and $\mathrm{AlO}_{4}{ }^{5-}$ tetrahedrally linked through shared oxygen atoms. ${ }^{[14,15]}$ In the presence of zeolite, Huiliñir et al. ${ }^{[4]}$ obtained a faster TAN removal rate and higher nitrate production compared to controls (systems without zeolite), because the inhibitory effect of both sulfur and organic matter in the nitrification process was reduced by $53 \%$ when zeolite was used as improver. Although the positive effect of zeolite on nitrification has been observed, a kinetic analysis of its effects through modelling of the process has not been presented until now. The use of modelling can elucidate which process could be stimulated or inhibited by zeolite, providing support in decision making for plant operation or developing new control schemes. ${ }^{[22]}$

According to these backgrounds, there is still a need to determine the kinetics of nitrification in the presence of sulfide and organic matter using an improver such as natural zeolite. Therefore, the main goal of this study was to determine and propose a kinetic model that incorporates explicitly the effect of zeolite on the nitrification process. The kinetic model was analyzed through sensitivity and collinearity analysis of the parameters, and this proposed model was then calibrated. According to Kostrysia et al. ${ }^{[23]}$, the sensitivity analysis allows to verify the stability of the model and identify which parameters must be optimized. To the best of our knowledge, this is the first time that the effect of zeolite as improver is incorporated explicitly in the kinetics of the nitrification process in the presence of both sulfide and organic compounds. 


\section{Material and methods}

\section{Kinetic Model}

The proposed kinetic model involves the following steps or processes: Total ammonia nitrogen (TAN) degradation by ammonium-oxidizing biomass (AOB), nitrite degradation by nitrite-oxidizing biomass (NOB), and COD removal by heterotrophic biomass (HB). Because of these degradation processes, the corresponding specific growth rates of all the biomass species (AOB, NOB and $\mathrm{HB}$ ) involved were taken into account and included in the model. Furthermore, the inhibition of TAN and nitrite oxidation by sulfide was also included based on the work of Bejarano et al. ${ }^{[7]}$ i.e. a non-competitive inhibition of sulfide on AOB and both competitive and noncompetitive inhibition of NOB. According to Huiliñir et al. ${ }^{[4]}$ sulfide was mainly oxidized by chemical reaction. Thus, the chemical oxidation of sulfide was also added. Therefore, the model included three biological species (AOB, NOB and HB) and 5 soluble species: TAN, nitrate $\left(\mathrm{NO}_{3}{ }^{-}\right)$, nitrite $\left(\mathrm{NO}_{2}{ }^{-}\right)$, organic matter $(\mathrm{COD})$ and sulfide $\left(\mathrm{H}_{2} \mathrm{~S}\right)$. It is important to note that oxygen was not included as a state variable in the model because according to previous experimental results, ${ }^{[4]}$ the oxygen concentration was always greater than $2 \mathrm{mg} / \mathrm{L}$, and was therefore not a limiting substrate.

According to these assumptions, the specific growth rates of AOB and NOB can be expressed as follows: ${ }^{[7,24]}$

$$
\begin{aligned}
& \mu_{A O B}=\mu_{\max , A O B} \cdot \frac{c_{N_{3}}}{K_{S, A O B}+c_{N_{3}}+\frac{c_{N H_{3}}{ }^{2}}{K_{I S, A O B}} \cdot \frac{K_{I, S, A O B}}{c_{H_{2 S}}+K_{I, S, A O B}}} \\
& \mu_{N O B}=\mu_{\max , N O B} \cdot \frac{c_{\mathrm{HNO}_{2}}}{K_{S, N O B} \cdot\left[1+\frac{c_{\mathrm{H}_{2} S}}{K_{I S u, N O B}}\right]+c_{H_{N 0_{2}}}+\frac{c_{\mathrm{HNO}_{2}}{ }^{2}}{K_{I S, N O B}} \cdot \frac{K_{I, S, N O B}}{c_{H_{2 S}}+K_{I, S, N O B}}}
\end{aligned}
$$


It is important to note that specific growth rates are in terms of only no ionized species. Thus, $\mathrm{NH}_{4}^{+} / \mathrm{NH}_{3}$ and $\mathrm{NO}_{2}^{-} / \mathrm{HNO}_{2}$ equilibria as a function of $\mathrm{pH}$ and temperature were also included in the kinetic model. The concentration of $\mathrm{NH}_{3}$ and $\mathrm{HNO}_{2}$ are related with TAN concentration and nitrite concentration by equations (3) and (4), respectively: ${ }^{[25]}$

$\begin{aligned} c_{\mathrm{NH}_{3}} & =\frac{c_{\mathrm{TAN}}}{1+\frac{10^{-p H}}{K_{d, N H_{3}}}} \\ c_{\mathrm{HNO}_{2}} & =\frac{c_{\mathrm{NO}_{2}{ }^{-}}}{1+10^{p H} \cdot K_{d, \mathrm{HNO}_{2}}}\end{aligned}$

where:

$K_{d, N H_{3}}=e^{-\frac{6344}{(T+273)}}$

$K_{d, H N O_{2}}=e^{-\frac{2300}{(T+273)}}$

The specific growth rate of HB was expressed as:

$\mu_{H}=\mu_{\max , H} \cdot \frac{c_{C O D}}{K_{S, C O D}+c_{C O D}}$

On the other hand, equations (8) to (16) present the mass balances in a batch system:

- Total ammonia nitrogen (TAN):

$\frac{d c_{T A N}}{d t}=-\frac{\mu_{A O B}}{Y_{A O B / T A N}} \cdot x_{A O B}$

- Total nitrite nitrogen $\left(\mathrm{NO}_{2}^{-}\right)$:

$\frac{d c_{\mathrm{NO}_{2}{ }^{-}}}{d t}=\frac{\mu_{A O B}}{Y_{A O B / T A N}} \cdot x_{A O B} \cdot f_{N_{2}{ }^{-} / T A N}-\frac{\mu_{N O B}}{Y_{\frac{N O B}{N O_{2}}}} \cdot x_{N O B}$

- Total nitrate nitrogen $\left(\mathrm{NO}_{3}^{-}\right)$:

$\frac{d c_{\mathrm{NO}_{3}{ }^{-}}}{d t}=\frac{\mu_{\mathrm{NOB}}}{Y_{\mathrm{NOB} / \mathrm{NO}_{2}{ }^{-}}} \cdot x_{\mathrm{NOB}} \cdot f_{\mathrm{NO}_{3}{ }^{-} / \mathrm{NO}_{2}{ }^{-}}$ 
- Organic matter as chemical oxidation demand (COD):

$\frac{d c_{C O D}}{d t}=-\frac{\mu_{H}}{Y_{H / C O D}} \cdot x_{H}$

- AOB:

$\frac{d x_{A O B}}{d t}=\left(\mu_{A O B}-k_{d}\right) \cdot x_{A O B}$

- NOB

$\frac{d x_{N O B}}{d t}=\left(\mu_{N O B}-k_{d}\right) \cdot x_{N O B}$

- HB

$\frac{d x_{H}}{d t}=\left(\mu_{H}-k_{d}\right) \cdot x_{H}$

- Sulfide: "The kinetic of sulfide oxidation was assumed as chemical reaction, support by our own experiments (see supplementary data) and other researchers ${ }^{[4] . ~ T h e ~ s u l f a t e ~}$ was not considered because it does not affect the nitrification process." According to Mora et al. ${ }^{[26]}$ sulfide oxidation under abiotic conditions can be represented by a $n t h$ order kinetics:

$\frac{d c_{H 2 S}}{d t}=-k_{H_{2} S} \cdot\left(c_{H_{2} S}\right)^{n}$

where $k_{H 2 S}$ is the kinetic constant for sulfide oxidation under abiotic conditions and $n$ is an order constant (dimensionless).

\section{Model implementation}

Model implementation, parameter identification, and calibration were carried out by a systematic procedure in order to obtain reliable model response and parameter uncertainty, ${ }^{[27]}$ based on available experimental data (Figure 1). 
The first step of the systematic procedure consists of a local sensitivity analysis, which was carried out using the method of Brun et al. ${ }^{[28]}$ The sensitivity analysis allows distinguishing the most sensitive parameters affecting the state variables (model outputs). According to Brun et al., ${ }^{[28]}$ the sensitivity of the model's output variable $y_{i}$ to small changes in the parameter values $p_{j}$ was considered. The sensitivity matrix is determined in equation 16 , where every column $v_{j}, \mathrm{j}=1,2, \ldots, \mathrm{m}$, represents the change in the model's outcome vector $y_{i}$ caused by a small change in $p_{j}$ (Equation 18). The scaled sensitivity matrix (Equation 17) proposed by Brun et al. ${ }^{[28]}$ to obtain sensitivity without dimensions was also considered.

$V=\frac{\partial y_{i}}{\partial p_{j}}$

$s_{i j}=v_{i j} \frac{p_{j}}{y_{i}}$

Where $v_{i j}$ denotes an element of $V$,

$p_{j}$ : a priori measure of the reasonable parameter range,

$y_{i}$ : scale factor with the same physical dimension as the corresponding observation (model output), accounting mainly for different scales of different output signals.

To obtain an order of importance of the parameters the three summaries proposed by Brun et al. ${ }^{[28]}$ were calculated.

$$
\begin{aligned}
\delta_{j}^{\text {msqr }} & =\sqrt{\frac{1}{n} \sum_{i=1}^{n} s_{i j}{ }^{2}} \\
\delta_{j}^{\text {mabs }} & =\frac{1}{n} \sum_{i=1}^{n}\left|s_{i j}\right| \\
\delta_{j}^{\text {mean }} & =\frac{1}{n} \sum_{i=1}^{n} s_{i j}
\end{aligned}
$$


According to the sensitivity analysis, the parameters with the largest sensitivity indices (mean, mabs, and mean) are selected, but there may be linear dependence on them. Because of it, a collinearity analysis was used. This was the second step of the procedure in order to detect the parameters with less linear dependence and/or lower eigenvalues based on their local sensitivity profile. ${ }^{[28]}$ The collinearity index $\left(\gamma_{k}\right)$ can be determined as follows:

$\gamma_{k}=\frac{1}{\sqrt{\lambda_{k}}}$

with $\lambda_{k}$ being the smallest eigenvalue of $\widetilde{{S_{K}}^{T}} S_{K}$

Once more-sensitive parameters were obtained, calibration with experimental data was performed. The initial values of the parameters were taken from the literature in order to start from a feasible real initial state point (Table 1). The adjustment was performed via a minimization of the NMSE error function presented in Eq. 22:

$N M S E=\sqrt{\sum_{i=1}^{N} \frac{\left(\left(y_{i}-y_{i, m}\right) /\left(y_{i, o}-y_{i}\right)\right)^{2}}{N}}$

where $y_{i}$ represents the concentration of the species measured experimentally, $y_{i, m}$ represents the model's calculated results, $y_{i, o}$ represents the species' inlet concentration, and $\mathrm{N}$ represents the amount of data. The error function was minimized with the Nonlinear Least squares (lsqcurvefit function in Matlab), and a numerical optimization method (optimset function in Matlab) determined the model's optimal parameters. Both calculation procedures were implemented using the Matlab R2014a. The numerical method used to solve the system of ordinary differential equations was the Gear method, which is included in Matlab R2014a for resolving stiff type equations. ${ }^{[29]}$ 
The Theil inequality coefficient, TIC ${ }^{[30]}$ was used as the criterion to compare the results of both models as suggested by Hvala et al. ${ }^{[31]}$ The value of TIC varies between 0 and 1 , where values closer to zero indicate a better model validity. The TIC is given by:

$T I C=\frac{\sqrt{\sum_{i}\left(y_{i}-y_{m, i}\right)^{2}}}{\sqrt{\sum_{i} y_{i}^{2}}+\sqrt{\sum_{i} y_{m, i}^{2}}}$

where $y_{i}$ represents the experimentally measured point and $y_{m, i}$ represents the model's prediction of the same point. The value of TIC lies between zero and one, and TIC values below 0.3 indicate good agreement with measured data. ${ }^{[31]}$

To determine the confidence interval or degree of uncertainty of the parameters, the bootstrap technique ${ }^{[32]}$ was applied, with a $95 \%$ confidence. Finally, the randomization analysis (residual error distribution) was performed using Statgraphics Centurion XVII.

The main parameters used in the model are listed in Table 1.

The initial biomass fractions used to solve the model were 0.67 and 0.33 for the active biomass and inert biomass, respectively. The active biomass ( 0.67 in fraction) was divided into nitrifying biomass (0.6) and heterotrophic biomass (0.07). ${ }^{[33]}$ Finally, the nitrifying biomass was divided into 0.77 for $\mathrm{AOB}$ and 0.23 for NOB. ${ }^{[34]}$ Therefore, the initial fractions of AOB, NOB, and HB were 0.462, 0.138, and 0.07, respectively. The model does not incorporate the generation of inert biomass.

\section{Experimental data}

The experimental data for calibration of the model were obtained from Huiliñir et al. ${ }^{[4]}$ Data of TAN, nitrite, nitrate, sulfide, sulfate, volatile suspended solids, and COD were used for this task. All the tested conditions and systems, as well as the experimental setup used, were described in detail in the mentioned paper. It is important to note that Huiliñir et al. ${ }^{[4]}$ indicated that in these experiments there was not biofilm formation on the zeolite. Therefore, 
the transport phenomena associated to biofilms (e.g., mass transfer) was not analyzed in this work, focusing mainly in the kinetic without mass transfer effect.

For the case of chemical sulfide oxidation, new experiments in abiotic conditions were performed in order to obtain the kinetic parameters. For this reason, the possibility of biological oxidation of sulfide was neglected.

. The experimental setup was the same presented by Huiliñir et al. ${ }^{[4]}$ Summarizing, 8 reactors of $300 \mathrm{~mL}$ each were used, with a liquid volume of $200 \mathrm{~mL}$ of synthetic wastewater. These bioreactors were sealed with rubber stoppers. All the assays were carried out at $25 \pm 2$ ${ }^{\circ} \mathrm{C}$, and the dissolved oxygen concentration was kept at $4.0 \pm 0.5 \mathrm{mg} / \mathrm{L}$ by continuous aeration. The air was injected through the bottom of the reactor using a porous ceramic diffuser that also kept the agitation inside the bioreactors. "Furthermore, the possible stripping of sulfide was neglected because the airflow rate used in all the experiments were small values, in order to prevent the stripping. Furthermore, the production of sulfate agreed with the sulfide oxidized, accomplishing the mass balance".

Five sulfide concentrations were used: 40, 60, 80, 100 and $160 \mathrm{mg} / \mathrm{L}$. In the kinetic assays, the sulfide concentration was measured every hour. Profiles obtained for each sulfide concentration are shown in the supplementary data (Figure S1). In order to determine $n$ and $k_{S 2}$, for each sulfide concentration, the maximum slope of the sulfide concentration vs. time plot was determined using Excel 2010 software. Then, each maximum slope was plotted against sulfide concentration. The values of the $n$ and $k_{S 2}$ parameters shown in Table 1 were determined by minimizing the error between the experimental maximum slope and the slope obtained with the kinetic model (Equation 15) through the solver analysis tool, included in Excel 2010 software. Figure 2 shows the results of the experimental slope and the model slopes, presenting a good fit with the model. 


\section{Results and discussions}

\section{Sensitivity analysis}

Tables 2 and 3 show the results of the parameter importance screening. Table 2 shows the results of the parameter ranking by varying the parameters $(+50 \%)$.

Table 3 shows the results of the parameter ranking by varying the parameters $(-50 \%)$.

The sensitivity threshold was set at $10 \%$ of the maximum $\delta$ msqr value calculated over all parameters according to Brun et al. ${ }^{[28]}$ With this value, 11 and 10 parameters were determined as insensitive, as shown in Table 2 and Table 3, respectively. The values of $\delta \mathrm{msqr}$ reflect the overall sensitivity of a parameter $j$ and allow identifying the order of importance of the parameters when the set of parameters to analyze is very large, as in this case. According to Brun et al. ${ }^{[28]}$ a comparison of $\delta$ mabs and $\delta$ mean shows whether all the elements of sensitivity have the same sign, and $\delta$ mean gives information on the sign of the averaged effect that a change in a parameter has on the model output. According to this, Table 2 and Table 3 show that only in the case of $K_{I . S . N O B}$ (both tables) and $\mu_{\max . N O B}$ (Table 3 ) all the elements of sensitivity have the same sign, indicating that these parameters increased the value of the model output (according to sensitive parameters).

The results of the sensitivity analysis lead to establish the preliminary set of potential identifiable parameters: $n, k_{S 2}, \mu_{\max , A O B}, \mu_{\max , N O B}, K_{I, S, A O B}, K_{I, S, N O B}$. This set presents the high sensitivity and presumably reflects higher model output perturbation.

\section{Collinearity analysis}

Results obtained from sensitivity analysis reflect that 6 parameters presented the highest sensitivity and reflect the highest model output perturbation. However, to complement this sensitivity analysis it is necessary to perform a collinearity analysis, since in the set of highly sensitive parameters (according to parameter importance ranking) there may be parameters that share their sensitivity profiles over time, thus balancing the effect of a change of value of 
a parameter with the modification of other parameters. Hence, the collinearity analysis allows selecting those most sensitive parameters that have the least linear dependence (Brun et al. [28]. Collinearity analysis is important due to the linear dependence between the parameters, which results in problems during optimization, increasing the uncertainty of the calibrated parameters. The results of the collinearity analysis are presented in Table 4 .

The parameters subset selected to carry out the calibration was chosen taking into account sensitivity analysis and collinearity results simultaneously. The parameter subset used for calibration comprises the subset parameters with most sensitivity (according to parameter importance ranking) and with a collinearity index lower than $10\left(\gamma_{k}=6.62\right)$. This means that not necessarily the lowest $\gamma_{k}$ of this subset dimension must be selected as parameters to calibrate. Therefore, the chosen subset is shown next (subset 1): n, $k_{S 2}, \mu_{\max }, A_{O B}, \mu_{\max , N O B}, K_{S}$,

NOB.

According to this analysis, even though the sulfide and organic matter are very important inhibitors, the more sensitivities parameters obtained are associated to the AOB and NOB growth. On the other hand, parameters associated to the chemical oxidation of sulfide produce a stronger effect on the process than the parameters associated to the inhibition. That means that the degradation (chemical or biological) of sulfide must be included in models that involve the presence of sulfide in a nitrifying bioreactor. On the other hand, the NOB kinetic has more sensitive parameters than AOB microorganism, because both $\mu_{\max , N O B}$ and $K_{S, N O B}$ affect in an important way the output's model. This result show the importance of $\mathrm{NOB}$ and the $\mathrm{NO}_{2}{ }^{-}$variables on the development of nitrification kinetic models. Finally, according to this analysis, the organic matter removal by heterotrophic biomass has not influence on the model's output of nitrification, at least at low organic matter concentrations. Therefore, standard values of kinetic parameters associated to heterotrophic biomass growth 
could be used in models that involve simultaneously the nitrification and organic matter removal in aerobic bioreactors.

\section{Model calibration and effect of zeolite on the parameters}

Once the sensitivity analysis showed which parameters should be calibrated, the calibration of the model was performed. Calibration was done with data coming from Huiliñir et al. ${ }^{[4]}$ in the presence of sulfide and organic matter, but without zeolite. The agreement between the calibrated model and the experimental data is shown in Figure 3 and the determined parameters are shown in Table 5. According to Figure 3, the model was able to represent qualitatively the experimental behavior of the system for all the variables studied in the system without zeolite. The model could represent both parts of the dynamic of the system, i.e. the slow degradation of TAN and production of $\mathrm{NO}_{3}{ }^{-}$in the first 5 hours and then the fast part of the process, with a higher TAN degradation rate and $\mathrm{NO}_{3}{ }^{-}$production. It is important to note that, according to experimental data, a very low concentration of nitrite was obtained, with a very strong activity of NOB. This behavior also was obtained by the model (data not shown).

The quantification of the good agreement was made by the TIC calculation, whose values for all the species were lower than $0.3\left(0.01,0.0018\right.$ and 0.04 for TAN, $\mathrm{NO}_{3}{ }^{-}$and $\mathrm{H}_{2} \mathrm{~S}$, respectively), confirming that the model is able to represent the activity of the nitrification process in the presence of sulfide and organic matter. To determine if the error has a normal distribution, the Shapiro Wilk test was applied using Statgraphics Centurion XVII, and it showed that the error has a normal distribution with $95 \%$ confidence, with values of $\mathrm{P}$ higher than $0.05\left(0.7220,0.3419\right.$ and 0.1160 for $\mathrm{TAN}, \mathrm{NO}_{3}{ }^{-}$and $\mathrm{H}_{2} \mathrm{~S}$ concentration, respectively).

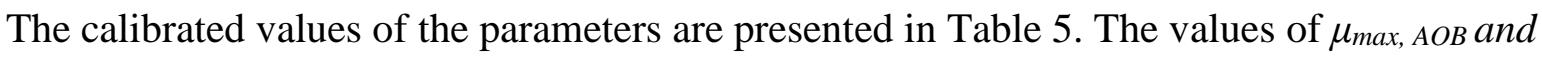
$K_{\text {S.NOB }}$ are within the range reported in the literature, ${ }^{[5,25,36-39]}$ with values closer to that reported by Wett \& Rauch. ${ }^{[37,40]}$ On the contrary, the values obtained for NOB parameters

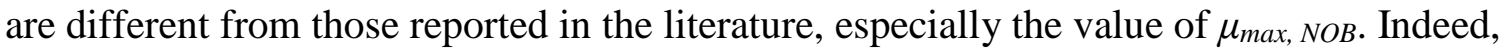


$\mu_{\max }$ NOВ was much greater than that reported in the literature. ${ }^{[25,37-40]}$ The values reported in the literature varied between 0.0208 and $0.075 \mathrm{~h}^{-1}$, while the value obtained here was 0.3307 $\pm(0.416) \mathrm{h}^{-1}$. Nevertheless, this high value is in agreement with the experimental results obtained, because the nitrite concentration was very low in all the recorded tests. A possible explanation of the fast removal of nitrite and then the high value of $\mu_{\max , N O B}$ could be the high oxygen concentration that allowed a very good performance of NOB in this experieces.

Once the parameters where calibrated for the experiments without zeolite, the effect of zeolite on the calibrated kinetic parameters was studied. The results are presented in Figure 4. According to Figure 4, the saturation constant of $\mathrm{NOB}\left(K_{S, N O B}\right.$, Figure $\left.4 \mathrm{a}\right)$ decreases with increasing zeolite concentration, which means that the presence of zeolite improves the affinity of NOB for the substrate. This parameter decreased by $44.78 \%$ ( $2.5 \mathrm{~g} / \mathrm{L}$ of zeolite), by $62.24 \%$ ( $5 \mathrm{~g} / \mathrm{L}$ of zeolite), by $76.15 \%$ (10 g/L of zeolite) and by $93.40 \%$ (15 g/L of zeolite) respect to the value obtained without zeolite. A possible explanation could be the higher availability of nitrite by the higher activity of AOB (see Fig. 4b), allowing then a higher NOB activity. Regarding to $\mu_{\max , A O B}$, Figure $4 \mathrm{~b}$ shows that there is an increasing of its value with respect to the values without zeolite. The increase varied between $16.57 \%$ at $2.5 \mathrm{~g} / \mathrm{L}$ of zeolite and $387 \%$ at $15 \mathrm{~g} / \mathrm{L}$ of zeolite, showing that zeolite concentration has a strong effect on the specific growth rate. That situation can be explained by the adsorption of $\mathrm{NH}_{4}{ }^{+}$on the zeolite, allowing a higher consumption of ammonium by AOB. In the case of $\mu_{\max , N O B}$ (Figure 4c), it decreases strongly in the presence of zeolite, from $24.19 \%$ at a zeolite concentration of $2.5 \mathrm{~g} / \mathrm{L}$ to $71.15 \%$ at a zeolite concentration of $15 \mathrm{~g} / \mathrm{L}$. This can be explained by the higher presence of nitrite that could affect the growth of NOB by inhibition. However, the value of $\mu_{\max , N O B}$ at a zeolite concentration $=15 \mathrm{~g} / \mathrm{L}$ is still quite high (around $0.1 \mathrm{~h}^{-1}$ ), situation that together to the lower $K_{S, N O B}$ values, allowing the fast consumption of nitrite and avoiding the presence of nitrite under these conditions. 
Finally, $n$ (Figure 4d) and $k_{S 2}$ (Figure 4e) increased with the use of zeolite, but their increase was not large. Parameter $n$ increased $3.10 \%$ ( $2.5 \mathrm{~g} / \mathrm{L}$ of zeolite), $4.51 \%$ (5 g/L of zeolite), $11.20 \%$ (10 g/L of zeolite), and 19.63\% (15 g/L of zeolite) with respect to the system without zeolite; for $k_{S 2}$, it increased 3.09\% (2.5 g/L of zeolite), 4.38\% (5 g/L of zeolite), $7.26 \%$ (10 $\mathrm{g} / \mathrm{L}$ of zeolite), and $9.02 \%(15 \mathrm{~g} / \mathrm{L}$ of zeolite) with respect to the system without zeolite. This showed that the chemical oxidation of sulfide is not dependent on zeolite.

From the results of the calibrated parameters obtained for different concentrations of zeolite, a function was adjusted according to their tendencies. Figure 4 shows the equations of the adjusted functions and their corresponding $\mathrm{R}^{2}$. It was found that the dependence on zeolite of the parameters $\mathrm{K}_{\mathrm{S}, \mathrm{NOB}}, \mathrm{n}, \mu_{\max }$, АОВ, $\mu_{\max , \text { NOB }}$ can be described by an exponential function, while the dependence of the parameter $\mathrm{k}_{\mathrm{S} 2}$ is linear with respect to zeolite concentration. In all cases, the adjustments were adequate, since $\mathrm{R}^{2}$ values were close to 1 . With the functions obtained for the different parameters, new simulations were made including these functions in the parameters, i.e.:

$$
\begin{aligned}
& K_{S, N O B}=2 \cdot 10^{-6} e^{-0.167 \cdot c(\text { zeolite })} \\
& \mu_{\text {max }, A O B}=0.0256 \cdot e^{0.1075 \cdot c(\text { zeolite })} \\
& \mu_{\text {max }, N O B}=0.3186 \cdot e^{-0.086 \cdot c(\text { zeolite })} \\
& k_{S 2}=0.0047 \cdot c(\text { zeolite })+0.8297 \\
& n=0.6508 \cdot e^{0.0118 \cdot c(\text { zeolite })}
\end{aligned}
$$

Figure 5 shows the results obtained by simulations using the dependence of the parameters on zeolite (equations 24 to 28), while Table 6 shows the TIC values. Good agreement was obtained between the data and model results, including the effect of zeolite on the kinetic parameters, with values of TIC between 0.109 and 0.007 , with all these values being lower than 0.3. It is interesting to note that the model was able to simulate the process behavior 
when the system changed its rate rapidly. For instance, at a zeolite concentration of $10 \mathrm{~g} / \mathrm{L}$ (Figure 5c), the TAN degradation rate increased very fast between the $7^{\text {th }}$ and the $9^{\text {th }}$ hours, a situation that was represented very well by the model, with TIC values for TAN, nitrate, and sulfide concentrations of $0.024,0.0056$, and 0.0863 , respectively. The same situation was observed at a zeolite concentration of $15 \mathrm{~g} / \mathrm{L}$ (Figure $5 \mathrm{~d}$ ), where the TAN degradation rate and nitrate production rate increased very fast between the $5^{\text {th }}$ and $7^{\text {th }}$ hours and whose TIC values were $0.098,0.005$, and 0.21 for TAN, nitrate, and sulfide concentrations, respectively. Another characteristic of the model was its capacity of simulating the long lag phase at a zeolite concentration of $2.5 \mathrm{~g} / \mathrm{L}$ (Figure $5 \mathrm{a}$ ), where the reaction rate started from the $5^{\text {th }}$ hour onward. Under this condition, the TIC values were $0.09,0.103$, and 0.007 for TAN, nitrate, and sulfide concentrations, respectively. Finally, at a zeolite concentration of $5 \mathrm{~g} / \mathrm{L}$ (Figure $5 b)$, the slight drop of TAN and the increase of $\mathrm{NO}_{3}{ }^{-}-\mathrm{N}$ also were very well simulated by the kinetic model, even though the TIC value for nitrate concentration was the highest obtained in all the tests $(\mathrm{TIC}=0.109)$. Thus, the function obtained for quantifying the effect of zeolite on the kinetics of nitrification can simulate properly the behavior and performance of the system under sulfide and organic matter inhibition.

The last point that was evaluated with the model was its capacity to obtain the values of COD and VSS reported experimentally. Table 7 shows the comparison of the final concentrations of VSS and COD predicted with the model and those reported in the literature ${ }^{[4]}$. The error between the model and experimental data was calculated as follows:

$\operatorname{Error}(\%)=\frac{y_{\text {literature }}-y_{\text {model }}}{y_{\text {literature }}} \cdot 100$

As can be seen in Table 7, the error values for both parameters (VSS and COD) and all the tested conditions were lower than $3.5 \%$, showing that the model was able to predict the concentrations of VSS and COD in the system. In the case of VSS, the model predicted 
values lower than the experimental data under all the conditions, with errors lower than $2.0 \%$. For the case of soluble COD concentration, the values obtained by the model were also lower than the experimental data with all the tested zeolite concentrations. The largest error was obtained for the test without zeolite, although this error was lower than $3.5 \%$. Thus, according to these results, the model was able to predict both the VSS and COD concentrations in the tests under all the conditions studied.

\section{Conclusions}

A kinetic model that included the effect of sulfide and organic matter on the nitrification process was successfully calibrated and simulated in the presence of zeolite. According to the sensitivity and collinearity analysis, five parameters were the most sensitive in the model, whose calibrated values were: $\mu_{\max , A O B}=0.02642 \pm 0.002 \mathrm{~h}^{-1} ; \mu_{\max }, N O B=0.3307 \pm 0.416 \mathrm{~h}^{-1}$; $K_{S, N O B}=1.65 \cdot 10^{-6} \pm 2.85 \cdot 10^{-6} \mathrm{mgHNO}_{2}-\mathrm{N} / \mathrm{L} ; k_{S 2}=0.8213 \pm 0.076$, and $n=0.6537 \pm 0.030$. Zeolite affected mainly the parameters associated with the nitrification process, whose dependence on the $\mathrm{K}_{\mathrm{S}, \mathrm{NOB}}, \mu_{\max , \mathrm{AOB}}$ and $\mu_{\max , \mathrm{NOB}}$ parameters can be described by an exponential function. A good agreement between the experimental data and the model's results including the effect of zeolite on the kinetic parameters was obtained, with TIC values between 0.109 and 0.007 for all the variables studied, with all these values being lower than 0.3 .

\section{Acknowledgements}

The authors acknowledge gratefully the financial support provided by FONDECYT (Chile) under Project 1170103 and PhD fellowship 21170147 awarded to L. Acosta-Cordero. This work is dedicated to the memory of our well esteemed and wonderful colleague Dr. Silvio Montalvo Martinez who recently passed away. 


\section{References}

[1] Carrera, J.; Jubany, I.; Carvallo, L.; Chamy, R.; Lafuente, J. Kinetic models for nitrification inhibition by ammonium and nitrite in a suspended and an immobilised biomass systems. Process Biochem. 2004, 39(9), 1159-1165.

https://doi.org/10.1016/S0032-9592(03)00214-0.

[2] Jeong, E.; Im, W.T., Kim, D.H.; Kim, M.S.; Kang, S.; Shin, H.S. Different susceptibility of bacterial community to silver nanoparticles in wastewater treatment systems. J. Environ. Sci. Health A 2014, 49(6), 685-693.

https://doi.org/10.1080/10934529.2014.865454.

[3] Boyle-Gotla, A.; Elefsiniotis, P. Biological nitrogen removal of ammonia-rich centrate in batch systems. J. Environ. Sci. Health A 2013, 48(3), 331-337.

https://doi.org/10.1080/10934529.2013.726903.

[4] Huiliñir, C.; Medina, R.; Montalvo, S.; Castillo, A.; Guerrero, L. Biological nitrification in the presence of sulfide and organic matter: effect of zeolite on the process in a batch system. J. Chem. Technol. Biotechnol. 2018, 93(8), 2390-2398. https://doi.org/10.1002/jctb.5587.

[5] Beristain, R.; Pérez, D.N.; González, G.; Gómez, J. Simultaneous oxidation of ammonium, p-cresol and sulfide using a nitrifying sludge in a multipurpose bioreactor: A novel alternative. Bioresour. Technol. 2011, 102(3), 3623-3625. https://doi.org/10.1016/j.biortech.2010.10.127

[6] De la Torre, A.; Beristain, R.; Damian, P.; Gómez, J. Sequential nitrificationdenitrification process for nitrogenous, sulfurous and phenolic compounds removal in the same bioreactor. Bioresour. Technol. 2013, 139, 220-225. 
https://doi.org/10.1016/j.biortech.2013.03.190.

[7] Bejarano, D.I.; Huerta, S.; Thalasso, F.; Cuervo, F.M.; Texier, A.C. Kinetic Constants for Biological Ammonium and Nitrite Oxidation Processes Under Sulfide Inhibition. Appl. Biochem. Biotechnol. 2015, 177(8), 1665-1675. https://doi.org/10.1007/s12010$\underline{015-1844-3}$.

[8] Kouba, V.; Proksova, E.; Wiesinger, H.; Vejmelkova, D.; Bartacek, J. Good servant, bad master: Sulfide influence on partial nitritation of sewage. Water Sci. Technol. 2017, 76(12), 3258-3268. https://doi.org/10.2166/wst.2017.490.

[9] Dos Santos, C.E.; Solcia, R.B.; Gouvea de Godoi, L.A.; Foresti, E.; Zamariolli, M.H. R. Dynamics of the nitrification and sulfide-driven autotrophic denitrification processes in a single reactor using oxidation-reduction potential as an indicator of the process effectiveness. J. Chem. Technol. Biotechnol. 2018, 93(12), 3483-3491. https://doi.org/10.1002/jctb.5707.

[10] Racz, L.A.; Datta, T.; Goel, R. Effect of organic carbon on ammonia oxidizing bacteria in a mixed culture. Bioresour. Technol. 2010, 101(16), 6454-6460. https://doi.org/10.1016/j.biortech.2010.03.058.

[11] He, Y.; Langenhoff, A.; Comans, R.; Sutton, N.B.; Rijnaarts, H. Effects of dissolved organic matter and nitrification on biodegradation of pharmaceuticals in aerobic enrichment cultures. Sci. Total Environ. 2018, 630, 1335-1342. https://doi.org/10.1016/j.scitotenv.2018.02.180.

[12] Chen, Y; Cheng, J; Creamer, K. Inhibition of anaerobic digestion process: A review. Bioresource Technology 2008, 99, 4044-4064. https://doi:10.1016/j.biortech.2007.01.057 
[13] Young, M.K.; Donghee, P.; Dae, S.L.; Jong, M.P. Inhibitory effects of toxic compounds on nitrification process for cokes wastewater treatment. Journal of Hazardous Materials 2008, 152, 915-921. https://doi.org/10.1016/j.jhazmat.2007.07.065

[14] Tashauoei, H.R.; Attar, H.M.; Amin, M.M.; Kamali, M.; Nikaeen, M.; Dastjerdi, M.V. Removal of cadmium and humic acid from aqueous solutions using surface modified nanozeolite A. Int. J. Environ. Sci. Technol. 2010, 7(3), 497-508. https://doi.org/10.1007/BF03326159.

[15] Montalvo, S.; Guerrero, L.; Borja, R. Improvement in nitrification through the use of natural zeolite: Influence of the biomass concentration and inoculum source. Int. J. Environ. Sci. Technol. 2014, 11(1), 43-52. https://doi.org/10.1007/s13762-013-0364-3.

[16] Guerrero, L.; Vasquez, M.; Barahona, A.; Montalvo, S.; Borja, R. Denitrification via nitrite in a modified UASB reactor using Chilean zeolite as microbial support. Int $J$ Environ Res 2013, 7, 17-26. https://doi.org /10.22059/IJER.2012.582

[17] Montalvo, S.; Huiliñir, C.; Galvez, D.; Roca, N.; Guerrero, L. Autotrophic denitrification with sulfide as electron donor: effect of zeolite, organic matter and temperature in batch and continuous UASB reactors. Int Biodeter Biodegrad 2016, 108, 158-165. https://doi.org/10.1016/j.ibiod.2015.12.022

[18] Yang, Y.; Chen, Z.; Wang, X.; Zheng, L.; Gu, X. Partial nitrification performance and mechanism of zeolite biological aerated filter for ammonium wastewater treatment. Bioresource Technol 2017, 473481. https://doi.org/10.1016/j.biortech.2017.05.151

[19] Huiliñir, C., Fuentes, V., Esposito, G., Montalvo, S., Guerrero, L. Nitrification in the presence of sulfide and organic matter in a sequencing moving bed biofilm reactor (SMBBR) with zeolite as biomass carrier. Journal of Chemical Technology \& Biotechnology 2020, 95, 173-182. https://doi.org/10.1002/jctb.6219 
[20] Montalvo, S.; Huiliñir, C.; Borja, R.; Sánchez, E.; Herrmann, C. Application of zeolites for biological treatment processes of solid wastes and wastewaters - A review. Bioresource Technology 2020, 301, 122808.

https://doi.org/10.1016/j.biortech.2020.122808

[21] Montalvo, S.; Díaz, F.; Guerrero, L.; Sánchez, E.; Milán, Z.; Cortés, I.; De la Rubia, M. Aplication of natural zeolite in anaerobic digestion processes: a Review. ELSEVIER 2012, 125-133. https://doi.org/10.1016/j.clay.2012.01.013

[22] López, C.M.; Buitrón, G.; García, H.A.; Cervantes, F.J. Tratamiento biológico de aguas residuales: Principios, modelación y diseño, Alliance House, 12 Caxton Street, London, 2017.

[23] Kostrytsia, A.; Papirio, S.; Mattei, M.R.; Frunzo, L.; Lens, P.N.L.; Esposito, G. Sensitivity analysis for an elemental sulfur-based two-step denitrification model. Water Sci. Technol 2018, 78(6), 1296-1303. https://doi.org/10.2166/wst.2018.398.

[24] Huiliñir, C.; Romero, R.; Muñoz, C.; Bornhardt, C.; Roeckel, M.; Antileo, C. Dynamic modeling of partial nitrification in a rotating disk biofilm reactor: Calibration, validation and simulation. Biochem. Eng. J. 2010, 52(1), 7-18. https://doi.org/10.1016/j.bej.2010.06.012.

[25] Trojanowicz, K.; Plaza, E.; Trela, J. Model extension, calibration and validation of partial nitritation-anammox process in moving bed biofilm reactor (MBBR) for reject and mainstream wastewater. Environ. Technol. 2019, 40(9), 1079-1100. https://doi.org/10.1080/09593330.2017.1397765.

[26] Mora, M.; López, L.R.; Lafuente, J.; Pérez, J.; Kleerebezem, R.; van Loosdrecht, M.C. M.; Gamisans, X.; Gabriel, D. Respirometric characterization of aerobic sulfide, thiosulfate and elemental sulfur oxidation by S-oxidizing biomass. Water Res. 2016, 89, 282-292. https://doi.org/10.1016/j.watres.2015.11.061. 
[27] Carrera, F.; Donoso, A.; Jeison, D.; Díaz, I.; Gonzalez, J.A.; Ruiz, G. Development, identification and validation of a mathematical model of anaerobic digestion of sewage sludge focusing on $\mathrm{H}_{2} \mathrm{~S}$ formation and transfer. Biochem. Eng. J. 2016, 112, 13-19. https://doi.org/10.1016/j.bej.2016.03.008.

[28] Brun, R.; Reichert, P.; Künsch, H.R. Practical identifiability analysis of large environmental simulation models. Water Resour. Res. 2001, 37(4), 1015-1030. https://doi.org/10.1029/2000WR900350.

[29] Shampine, L.F.; Reichelt, M.W. The MATLAB ODE Suite. SIAM J. Sci. Comput. 1997, 18(1), 1-22. https://doi.org/10.1137/S1064827594276424.

[30] Theil, H. Economic Forecasts and Policy, North-Holland, Amsterdam, 1970.

[31] Hvala, N.; Strmčnik, S.; Šel, D.; Milanič, S.; Banko, B. Influence of model validation on proper selection of process models-an industrial case study. Comput. Chem. Eng. 2005, 29(7), 1507-1522. https://doi.org/10.1016/j.compchemeng.2004.11.013.

[32] López, A.; Elosua, P. Estimacion bootstrap para el coeficiente de determinación: un estudio de simulación. Revista Electrónica de Metodología Aplicada, 2004, 9(2), 1-14. https://doi.org/10.17811/rema.9.2.2004.1-14.

[33] Wiesmann, U. Biological nitrogen removal from wastewater. Adv. Biochem. Eng. Biotechnol., 1994, 51, 113-154. https://doi.org/10.1007/bfb0008736.

[34] Henze, M.; Harremoes, P.; Jansen, J.C.; Arbin, E. Wastewater treatment. Biological Chemical Processes. New York, 1997.

[35] Rittmann, B.E.; McCarty, P.L. Environmental Biotechnology: Principles and Applications. McGraw-Hill Series in Water Resources and Environmental Engineering, McGraw-Hill Education, 2001. 
[36] Bernet, N.; Sanchez, O.; Cesbron, D.; Steyer, J.P.; Delgenès, J.P. Modeling and control of nitrite accumulation in a nitrifying biofilm reactor. Biochem. Eng. J. 2005, 24(2), 173-183. https://doi.org/10.1016/j.bej.2005.02.002.

[37] Wett, B.; Rauch W. The role of inorganic carbon limitation in biological nitrogen removal of extremely ammonia concentrated wastewater. Water Res. 2003, 37(5), 1100-1110. https://doi.org/10.1016/S0043-1354(02)00440-2.

[38] Sin, G.; Niville, K.; Bachis, G.; Jiang, T.; Nopens, I.; van Hulle, S.; Vanrolleghem, P. A. Nitrite effect on the phosphorus uptake activity of phosphate accumulating organisms (PAOs) in pilot-scale SBR and MBR reactors. Water SA 2008, 34(2), 249260. https://doi.org/10.4314/wsa.v34i2.183646.

[39] Kampschreur, M.J.; van der Star, W.R.L.; Wielders, H.A.; Mulder, J.W.; Jetten, M.S.M.; van Loosdrecht, M.C.M. Dynamics of nitric oxide and nitrous oxide emission during full-scale reject water treatment. Water Res. 2008, 42(3), 812-826. https://doi.org/10.1016/j.watres.2007.08.022.

[40] Tao, C.; Hamouda, M.A. Steady-state modeling and evaluation of partial nitrificationanammox (PNA) for moving bed biofilm reactor and integrated fixed-film activated sludge processes treating municipal wastewater. J. Water Process Eng. 2019, 31, 100854. https://doi.org/10.1016/j.jwpe.2019.100854. 


\section{TABLES}

Table 1: Model initial parameters before optimization for a nitrification process in the presence of sulfide and organic matter

\begin{tabular}{|c|c|c|c|}
\hline Parameter & Value & Unit & Reference \\
\hline$\mu_{\max . A O B}$ & 0.032 & $\mathrm{~h}^{-1}$ & [25] \\
\hline$K_{S . A O B}$ & 0.028 & $\mathrm{mgNH}_{3}-\mathrm{N} / \mathrm{L}$ & [25] \\
\hline$K_{I S . A O B}$ & 540 & $\mathrm{mgNH}_{3}-\mathrm{N} / \mathrm{L}$ & [25] \\
\hline$K_{D O . A O B}$ & 0.3 & $\mathrm{mgO}_{2} / \mathrm{L}$ & [25] \\
\hline$K_{I . S . A O B}$ & $2.54 \pm 0.01$ & $\mathrm{mgHS}^{-}-\mathrm{S} / \mathrm{L}$ & [7] \\
\hline$\mu_{\max . N O B}$ & 0.045 & $\mathrm{~h}^{-1}$ & [25] \\
\hline$K_{S . N O B}$ & $3.2 \cdot 10^{-5}$ & $\mathrm{mg} \mathrm{HNO} 2-\mathrm{N} / \mathrm{L}$ & [25] \\
\hline$K_{I S . N O B}$ & 0.26 & $\mathrm{mg} \mathrm{HNO} 2-\mathrm{N} / \mathrm{L}$ & [25] \\
\hline$K_{D O . N O B}$ & 1.1 & $\mathrm{mgO}_{2} / \mathrm{L}$ & [25] \\
\hline$K_{I . S . N O B}$ & $1.03 \pm 0.06$ & $\mathrm{mgHS}^{-}-\mathrm{S} / \mathrm{L}$ & [7] \\
\hline$K_{I S u . N O B}$ & $0.22 \pm 0.03$ & $\mathrm{mgHS}^{-}-\mathrm{S} / \mathrm{L}$ & [7] \\
\hline$\mu_{\max . H}$ & 0.25 & $\mathrm{~h}^{-1}$ & [17] \\
\hline$K_{S . C O D}$ & 20 & $\mathrm{mgCOD} / \mathrm{L}$ & [17] \\
\hline$K_{D O . H}$ & 0.2 & $\mathrm{mgO}_{2} / \mathrm{L}$ & [17] \\
\hline$k_{d . A}$ & 0.002 & $\mathrm{~h}^{-1}$ & [25] \\
\hline$k_{d . H}$ & 0.0083 & $\mathrm{~h}^{-1}$ & [26] \\
\hline$k_{S 2}$ & 0.7355 & - & - \\
\hline$n$ & 0.6369 & - & - \\
\hline$Y_{A O B / T A N}$ & 0.147 & $\mathrm{mg} \mathrm{SSV/mgTAN}$ & [25] \\
\hline$f_{N O 2-/ T A N}$ & 0.98 & $\mathrm{mgNO}_{2}{ }^{-} / \mathrm{mgTAN}$ & [25] \\
\hline$Y_{\mathrm{NOB} / \mathrm{NO} 2}$ & 0.042 & $\mathrm{mgSSV} / \mathrm{mgNO}_{2}^{-}$ & [25] \\
\hline$f_{N O 3-/ N O 2-}$ & 1 & $\mathrm{mgNO}_{3}{ }^{-} / \mathrm{mgNO}_{2}^{-}$ & [25] \\
\hline$Y_{H / C O D}$ & 0.28 & $\mathrm{mg} \mathrm{SSV} / \mathrm{mgCOD}$ & [26] \\
\hline
\end{tabular}


Table 2: Parameter importance ranking (+50\% parameters)

\begin{tabular}{|c|c|c|c|}
\hline Parameters & $\delta m s q r$ & $\delta$ mabs & Smean \\
\hline$n$ & 4.91 & 2.76 & -0.12 \\
\hline$k_{S 2}$ & 4.19 & 2.17 & -0.08 \\
\hline$\mu_{\max . A O B}$ & 1.84 & 0.89 & $-8.00 \cdot 10^{-3}$ \\
\hline$\mu_{\max . N O B}$ & 1.31 & 0.54 & $-4.08 \cdot 10^{-6}$ \\
\hline$K_{I . S . A O B}$ & 1.28 & 0.66 & $-6.04 \cdot 10^{-3}$ \\
\hline$K_{I . S . N O B}$ & 0.72 & 0.32 & $1.49 \cdot 10^{-5}$ \\
\hline$K_{S . N O B}$ & 0.51 & 0.25 & $-3.01 \cdot 10^{-6}$ \\
\hline$K_{I S U ~ N O B}$ & 0.42 & 0.19 & $2.21 \cdot 10^{-5}$ \\
\hline$K_{O 2 . N O B}$ & 0.20 & 0.08 & $-8.94 \cdot 10^{-7}$ \\
\hline$K_{O 2 . A O B}$ & 0.10 & 0.04 & $4.34 \cdot 10^{-4}$ \\
\hline$k_{d . A}$ & 0.03 & 0.02 & $7.49 \cdot 10^{-5}$ \\
\hline$K_{I S . A O B}$ & 0.02 & 0.01 & $-1.08 \cdot 10^{-4}$ \\
\hline$\mu_{\text {max.HET }}$ & 0.01 & 0.01 & $2.78 \cdot 10^{-5}$ \\
\hline$K_{S . A O B}$ & 0.01 & $6 \cdot 10^{-3}$ & $6.96 \cdot 10^{-5}$ \\
\hline$K_{S . C O D}$ & $2.19 \cdot 10^{-3}$ & $9 \cdot 10^{-4}$ & $2.46 \cdot 10^{-7}$ \\
\hline$K_{I S . N O B}$ & $1.16 \cdot 10^{-3}$ & $4.3 \cdot 10^{-4}$ & $1.23 \cdot 10^{-6}$ \\
\hline$K_{O 2 . H E T}$ & $6.60 \cdot 10^{-4}$ & $2.80 \cdot 10^{-4}$ & $1.66 \cdot 10^{-5}$ \\
\hline$k_{d . H}$ & $4.70 \cdot 10^{-4}$ & $1.95 \cdot 10^{-4}$ & $-2.16 \cdot 10^{-7}$ \\
\hline
\end{tabular}


Table 3: Parameter importance ranking (-50\% parameters)

\begin{tabular}{|c|c|c|c|}
\hline Parameters & $\delta \mathrm{msqr}$ & סmabs & omean \\
\hline$n$ & 6.26 & 3.79 & -0.28 \\
\hline$k_{S 2}$ & 6.04 & 3.52 & -0.23 \\
\hline$\mu_{\max . A O B}$ & 3.12 & 1.81 & -0.02 \\
\hline$\mu_{\max . N O B}$ & 2.44 & 1.15 & $3.48 \cdot 10^{-6}$ \\
\hline$K_{I . S . A O B}$ & 2.28 & 1.19 & -0.01 \\
\hline$K_{I . S . N O B}$ & 1.32 & 0.61 & $1.18 \cdot 10^{-5}$ \\
\hline$K_{S . N O B}$ & 0.81 & 0.37 & $-1.43 \cdot 10^{-5}$ \\
\hline$K_{I S U ~ N O B}$ & 0.78 & 0.37 & $-1.38 \cdot 10^{-5}$ \\
\hline$K_{O 2 . N O B}$ & 0.22 & 0.09 & $-1.68 \cdot 10^{-5}$ \\
\hline$K_{O 2 . A O B}$ & 0.10 & 0.04 & $4.80 \cdot 10^{-4}$ \\
\hline$k_{d . A}$ & 0.03 & 0.02 & $7.24 \cdot 10^{-5}$ \\
\hline$K_{I S . A O B}$ & 0.07 & 0.03 & $-3.56 \cdot 10^{-4}$ \\
\hline$\mu_{\max . H E T}$ & 0.01 & 0.01 & $5.90 \cdot 10^{-5}$ \\
\hline$K_{S . A O B}$ & 0.01 & $6 \cdot 10^{-3}$ & $4.00 \cdot 10^{-5}$ \\
\hline$K_{S . C O D}$ & $2.47 \cdot 10^{-3}$ & $1.12 \cdot 10^{-3}$ & $-4.59 \cdot 10^{-6}$ \\
\hline$K_{I S . N O B}$ & $3.63 \cdot 10^{-3}$ & $1.35 \cdot 10^{-3}$ & $-1.02 \cdot 10^{-6}$ \\
\hline$K_{O 2 . H E T}$ & $5.2 \cdot 10^{-4}$ & $2.50 \cdot 10^{-4}$ & $-1.787 \cdot 10^{-6}$ \\
\hline$k_{d . H}$ & $4.4 \cdot 10^{-4}$ & $2.04 \cdot 10^{-4}$ & $-3.67 \cdot 10^{-7}$ \\
\hline
\end{tabular}


Table 4: Subsets of parameters with the lower collinearity index value (lower than 10)

\begin{tabular}{lc} 
Subset & $\gamma_{k}$ \\
\hline 1. n, $k_{S 2}, \mu_{\max , A O B}, \mu_{\max , N O B,} K_{S, N O B}$ & 6.62 \\
2. n, $k_{S 2}, \mu_{\max , N O B}, K_{I, S, A O B,} K_{S, N O B}$ & 7.41 \\
3. n, $k_{S 2}, \mu_{\max , A O B}, K_{I, S, A O B}$ & 6.53 \\
4. n, $k_{S 2}, K_{I, S, A O B}, K_{I, S, N O B}$ & 7.57 \\
5. n, $k_{S 2}, K_{I, S, A O B}, K_{S, N O B}, K_{I S u, N O B}$ & 7.98 \\
\hline
\end{tabular}


Table 5: Calibrated model parameters values obtained, with their confidence interval (CI)

\begin{tabular}{c|l|l|l}
\hline Parameter & Calibrated value $(\mathbf{C I})$ & $\begin{array}{c}\text { Reference } \\
\text { value }\end{array}$ & Author \\
\hline $\mathrm{N}$ & $0.653 \pm(0.030)$ & 0.6369 & - \\
$k_{S 2}$ & $0.821 \pm(0.076)$ & 0.7355 & - \\
$\mu_{\max . A O B}\left(\mathrm{~h}^{-1}\right)$ & $0.026 \pm(0.002)$ & 0.032 & {$[24]$} \\
$\mu_{\max . N O B}\left(\mathrm{~h}^{-1}\right)$ & $0.330 \pm(0.416)$ & 0.045 & {$[24]$} \\
$K_{S . N O B}\left(\mathrm{mg} \mathrm{HNO}_{2}-\mathrm{N} / \mathrm{L}\right)$ & $1.65 \cdot 10^{-6} \pm\left(2.85 \cdot 10^{-6}\right)$ & $3.2 \cdot 10^{-5}$ & {$[24]$} \\
\hline
\end{tabular}


Table 6: TIC values for the proposed model using the function of the calibrated parameters with the zeolite concentration

\begin{tabular}{c|llll}
\hline \multirow{2}{*}{ Variable } & \multicolumn{5}{|l}{ Zeolite concentration $(\mathrm{g} / \mathrm{L})$} \\
\cline { 2 - 5 } & $\mathbf{2 . 5}$ & $\mathbf{5}$ & $\mathbf{1 0}$ & $\mathbf{1 5}$ \\
\hline$C_{\mathrm{TAN}}$ & 0.090 & 0.034 & 0.024 & 0.098 \\
$C_{\mathrm{NO}_{3}{ }^{-}}$ & 0.013 & 0.109 & 0.0056 & 0.005 \\
$C_{\mathrm{H}_{2} \mathrm{~S}}$ & 0.007 & 0.0082 & 0.0783 & 0.021 \\
\hline
\end{tabular}


Table 7: Comparison of the final concentrations of VSS and COD calculated with the model and those reported in the literature

\begin{tabular}{|c|c|c|c|c|c|c|}
\hline \multirow{2}{*}{$\begin{array}{l}\text { Zeolite } \\
\text { concentration (g/L) }\end{array}$} & \multicolumn{3}{|c|}{ VSS (mg/L) } & \multicolumn{3}{|c|}{ Soluble COD $(\mathrm{mg} / \mathrm{L})$} \\
\hline & $\begin{array}{l}\text { Huiliñir et } \\
\text { al. }{ }^{[4]}\end{array}$ & Model & $\begin{array}{l}\text { Error } \\
(\%)\end{array}$ & $\begin{array}{l}\text { Huiliñir et } \\
\text { al. }{ }^{[4]}\end{array}$ & Model & $\begin{array}{l}\text { Error } \\
(\%)\end{array}$ \\
\hline 0 (model calibration) & 755 & 747 & 1.059 & 82.773 & 79.943 & 3.419 \\
\hline 2.5 & 745 & 735 & 1.342 & 86.183 & 83.825 & 2.736 \\
\hline 5 & 567 & 558 & 1.587 & 86.183 & 83.987 & 2.548 \\
\hline 10 & 677 & 664 & 1.920 & 82.846 & 80.876 & 2.377 \\
\hline 15 & 653 & 647 & 0.919 & 88.481 & 86.818 & 1.879 \\
\hline
\end{tabular}




\section{FIGURE CAPTIONS}

Figure 1: Systematic procedure applied for model implementation, calibration, and validation (Carrera et al. 2016).

Figure 2: Adjustment of the sulfide chemical oxidation model for the determination of $n$ and $k_{S 2}$

Figure 3: Model calibration for the system without zeolite. TAN removal, H2S removal, and nitrate production.

Figure 4: Effect of zeolite on the calibrated kinetic parameters.

Figure 5: Model simulations using functions in terms of zeolite concentrations. a) zeolite concentration $=2.5 \mathrm{~g} / \mathrm{L} ; \mathrm{b}$ ) zeolite concentration $=5 \mathrm{~g} / \mathrm{L} ; \mathrm{c})$ zeolite concentration $=10 \mathrm{~g} / \mathrm{L} ; \mathrm{d}$ ) zeolite concentration $=15 \mathrm{~g} / \mathrm{L}$. 


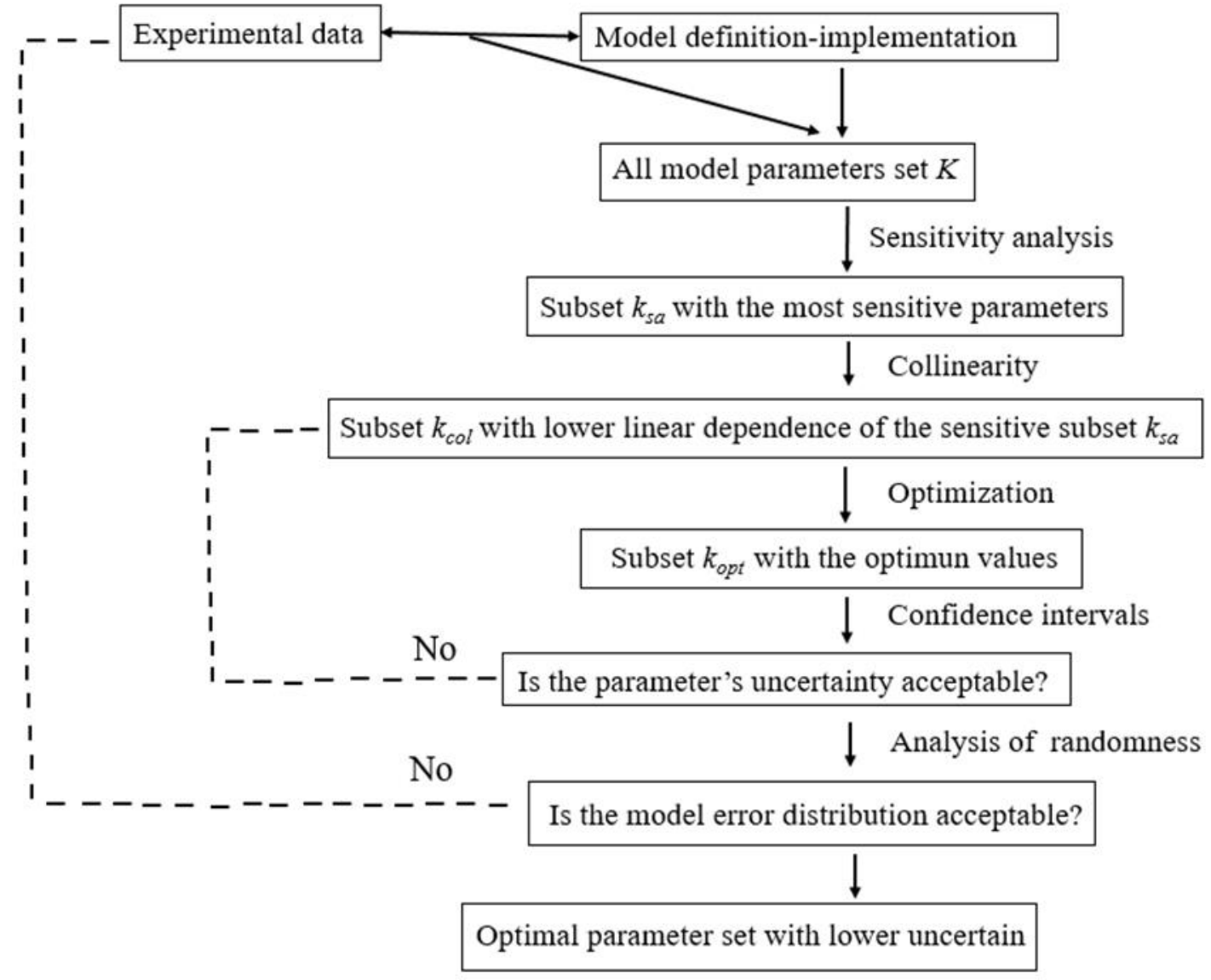

Figure 1 


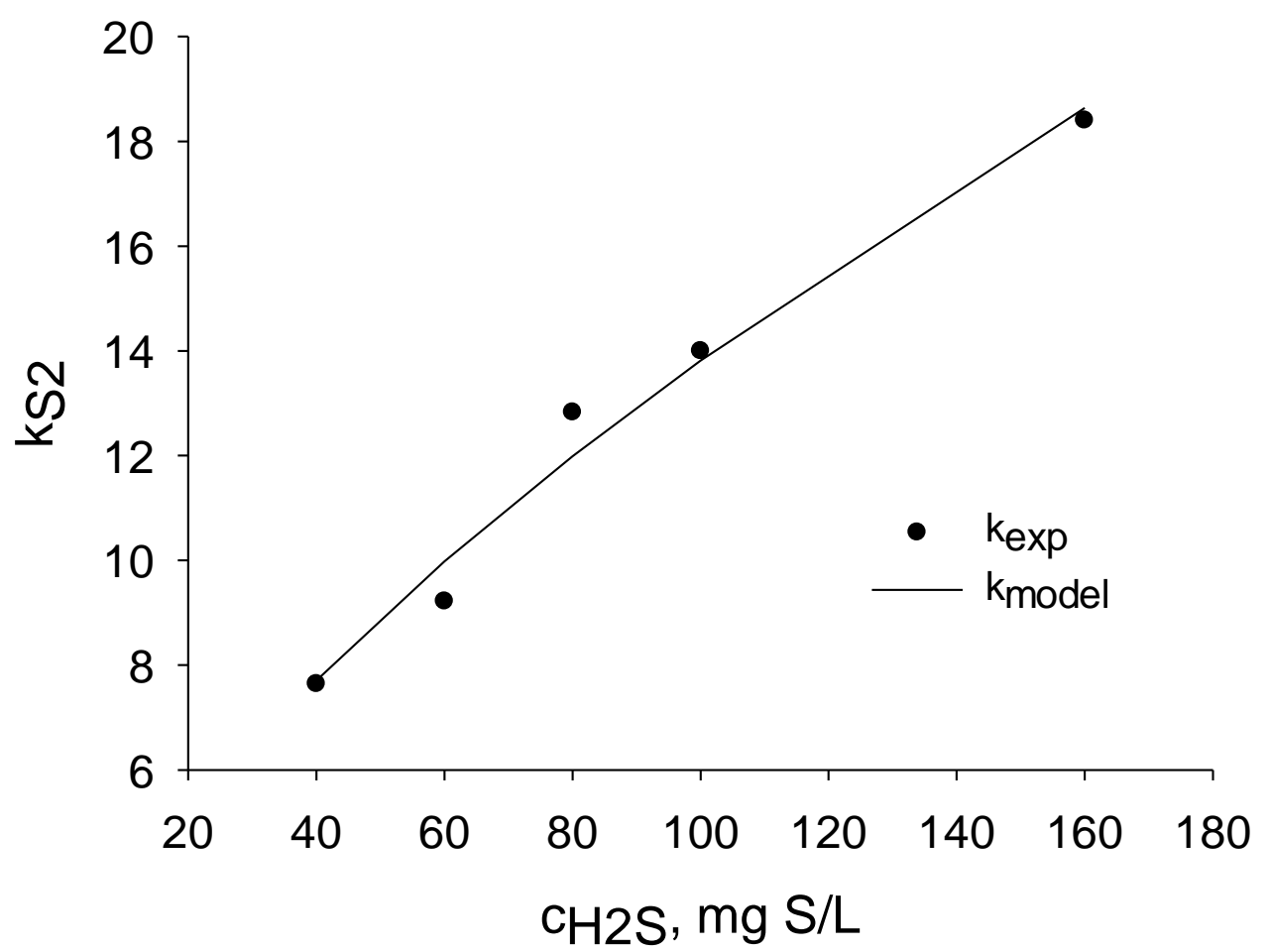

Figure 2 


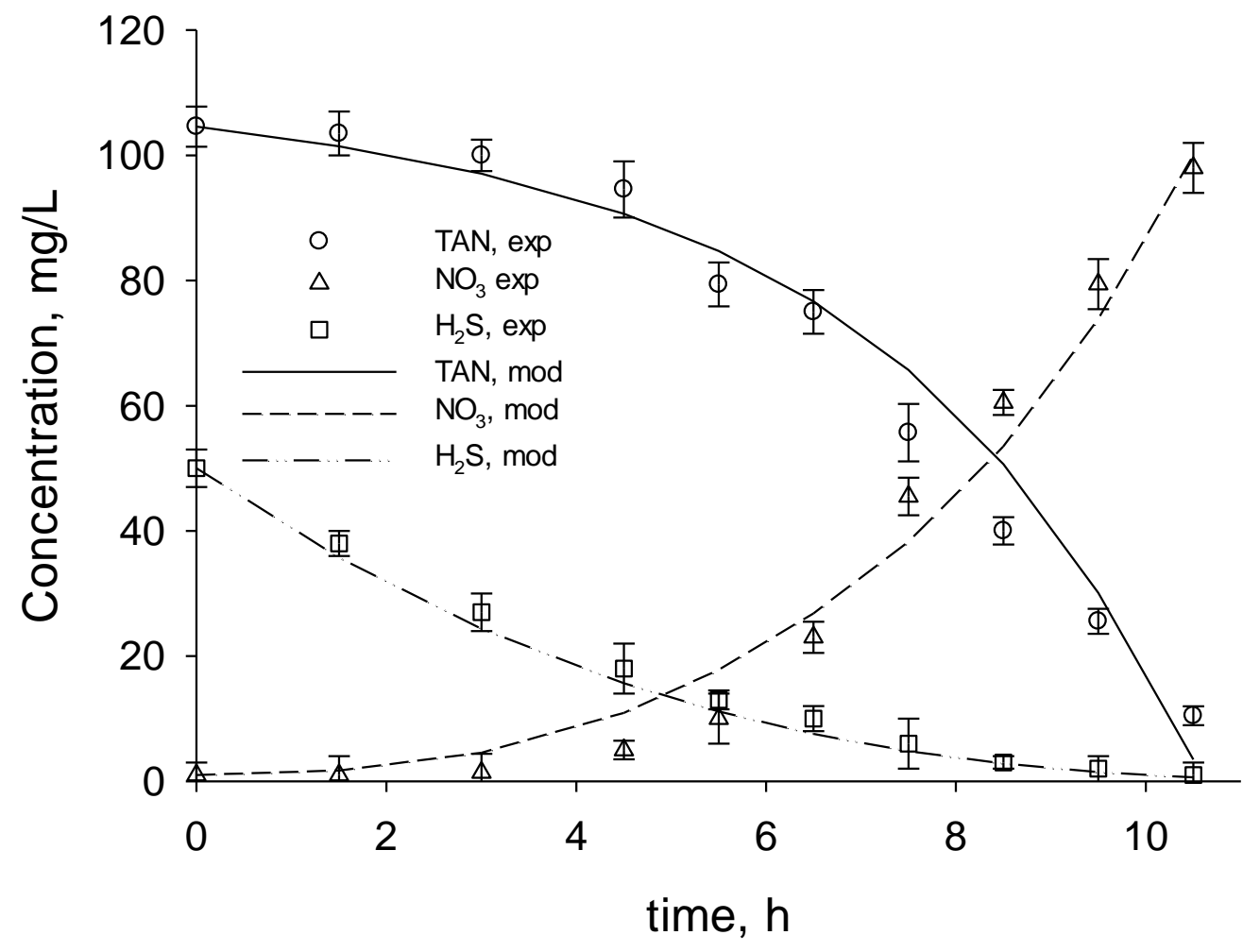

Figure 3 

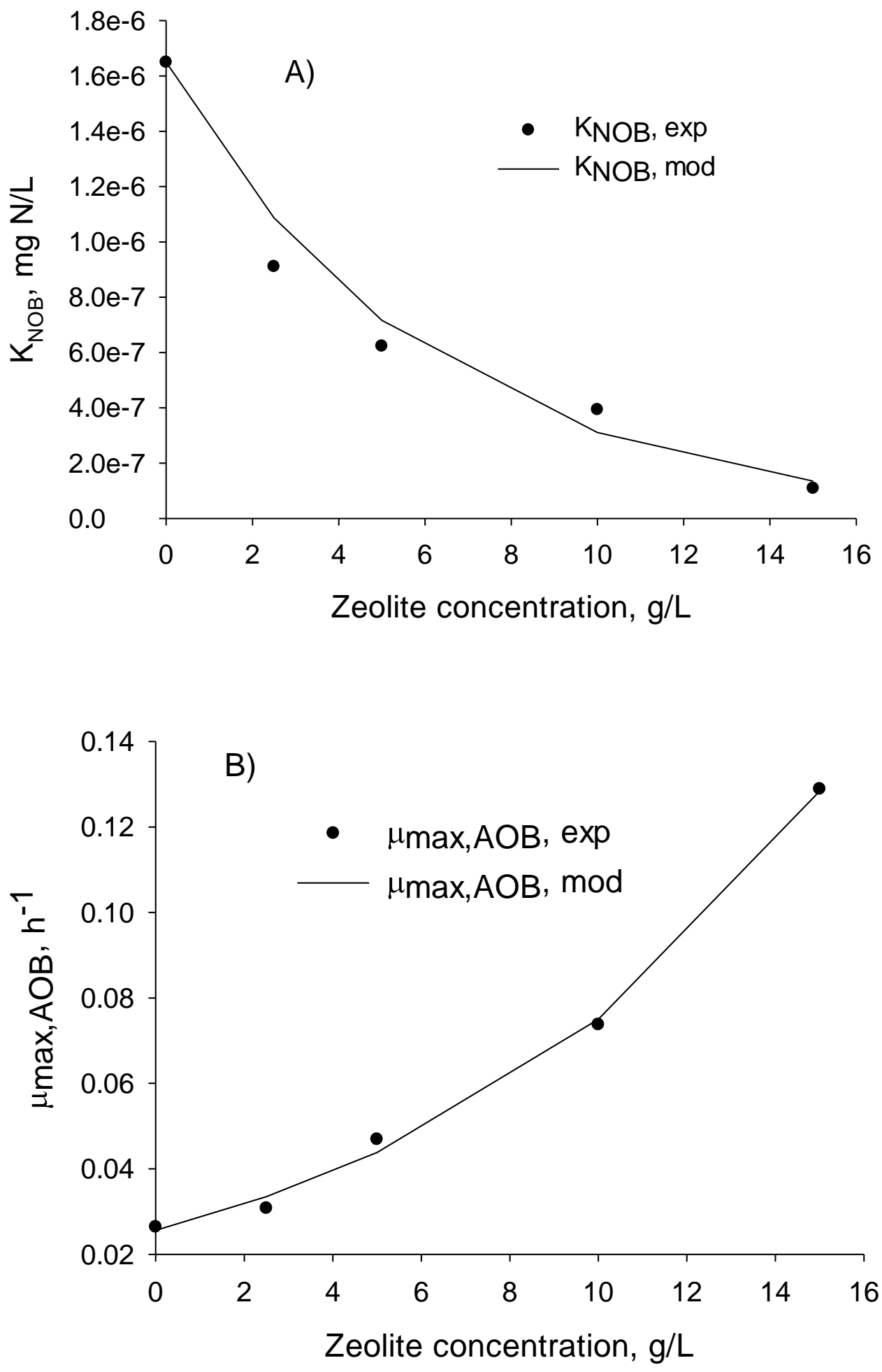

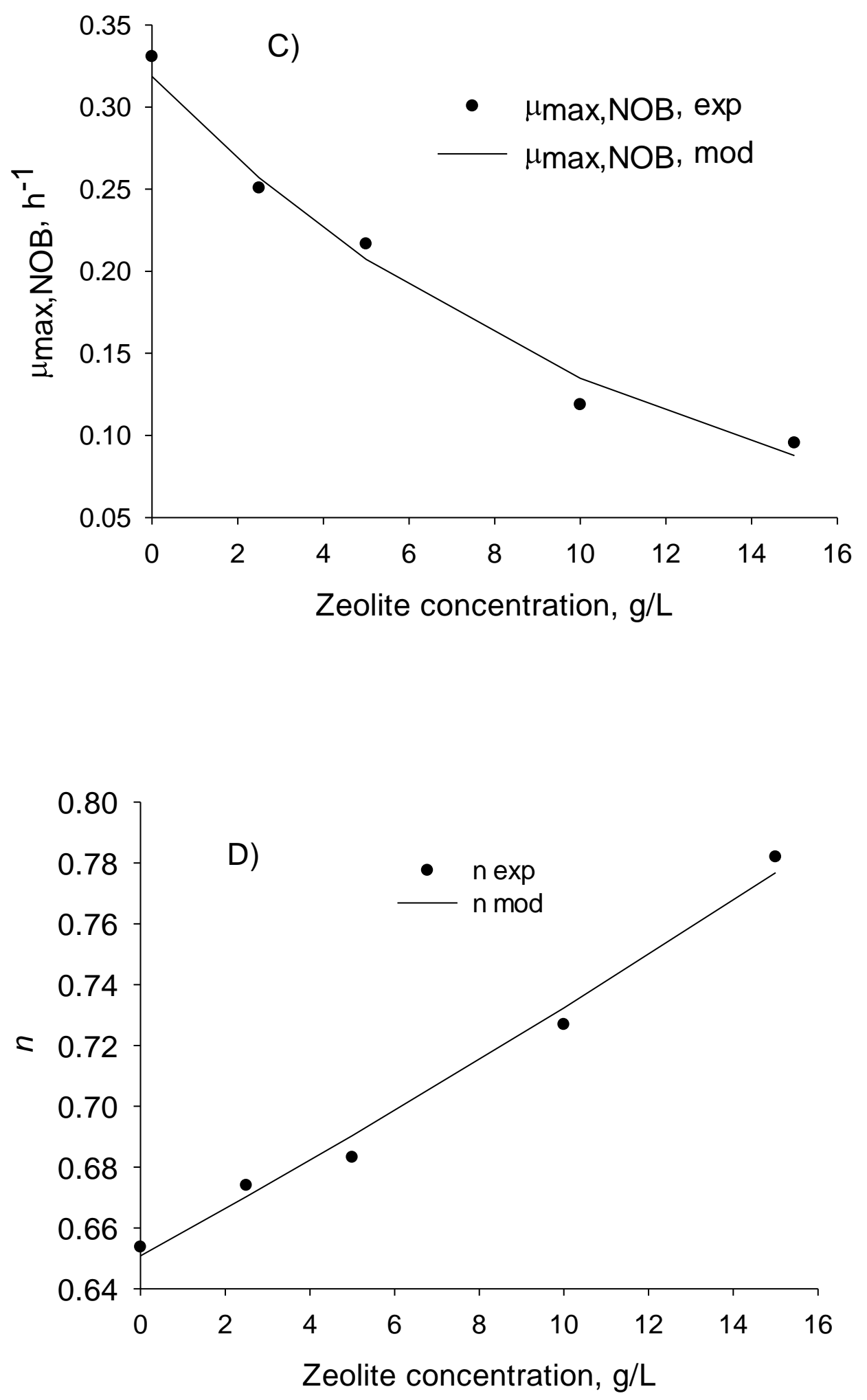


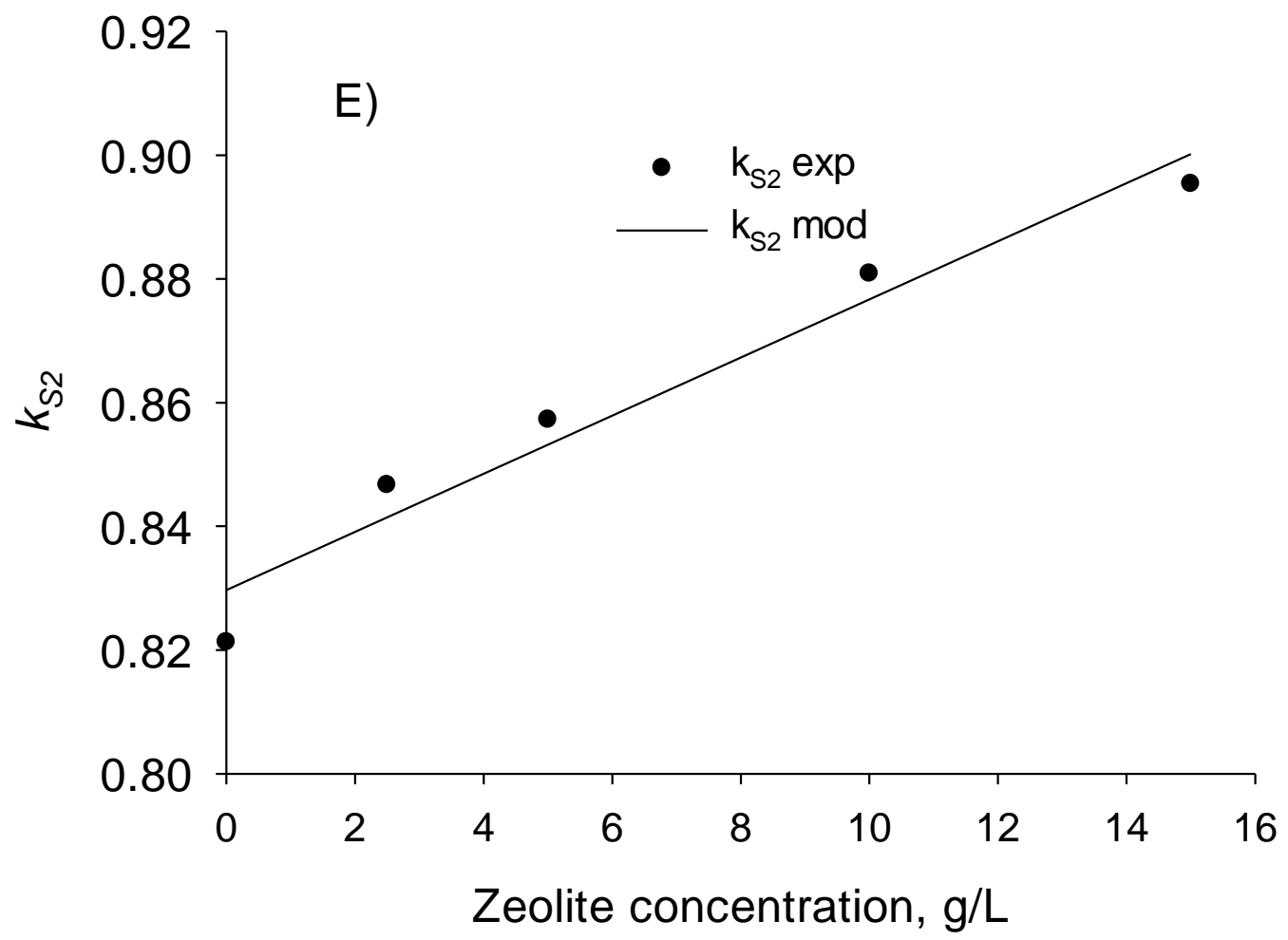

Figure 4 

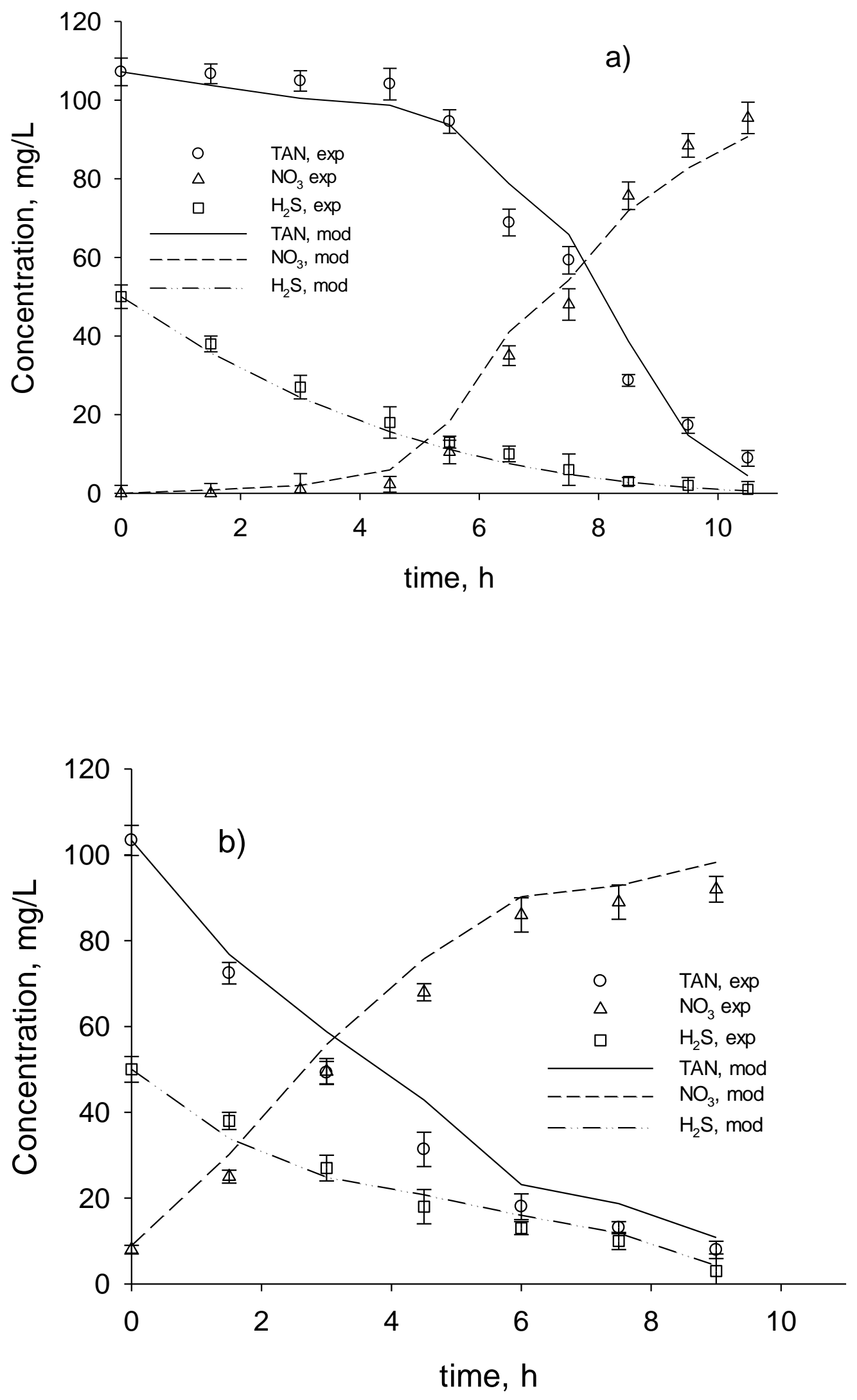

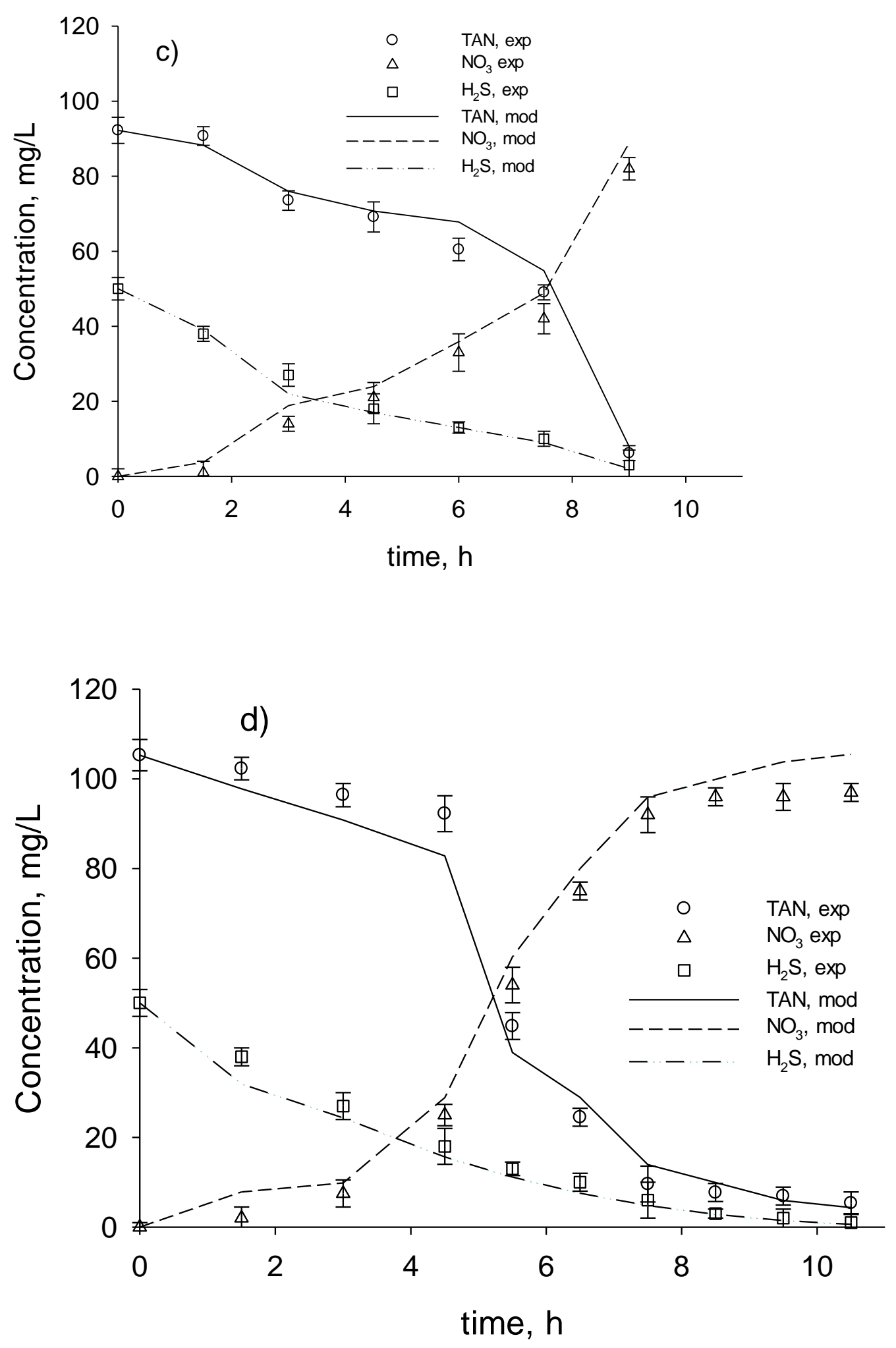

Figure 5 

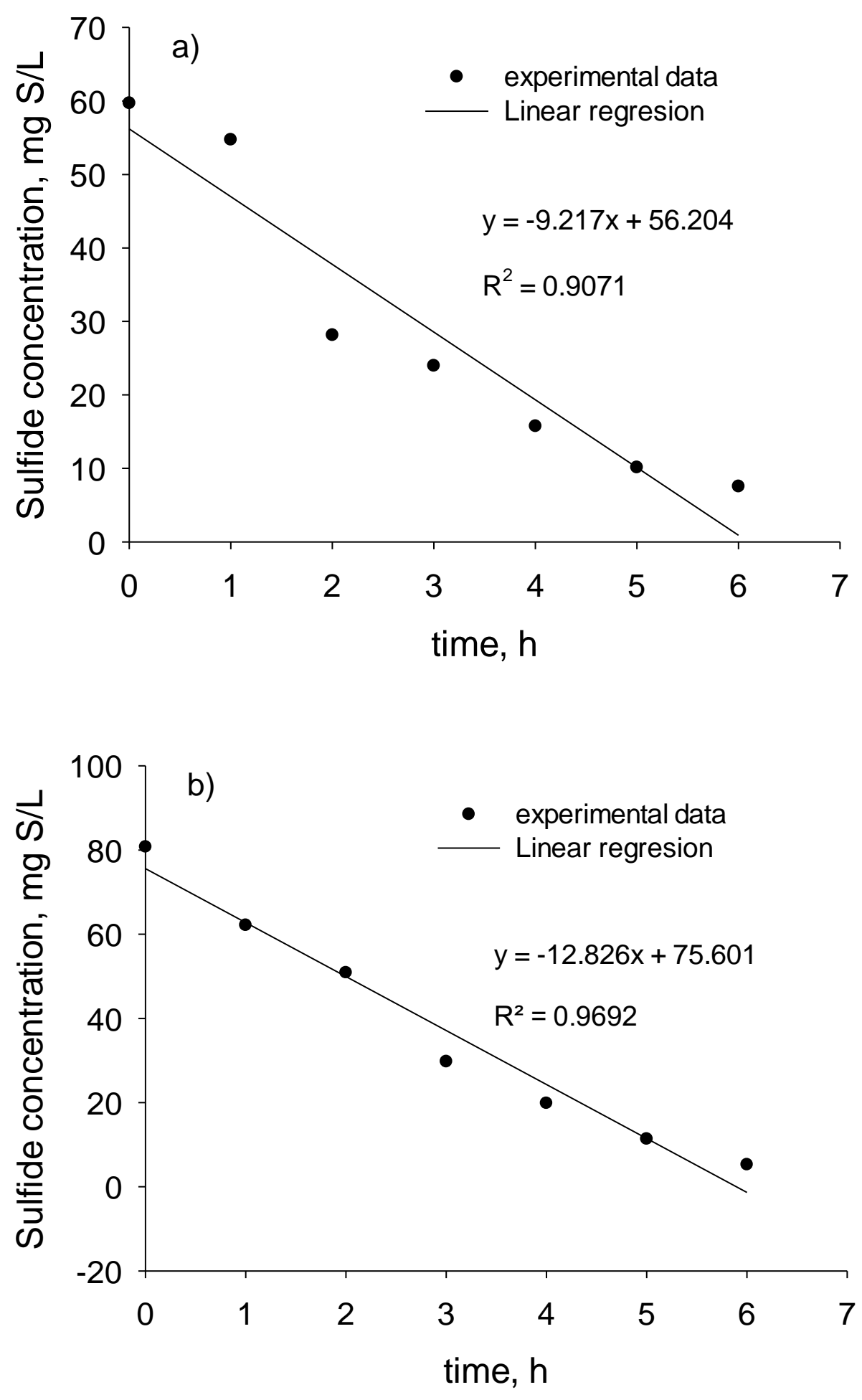

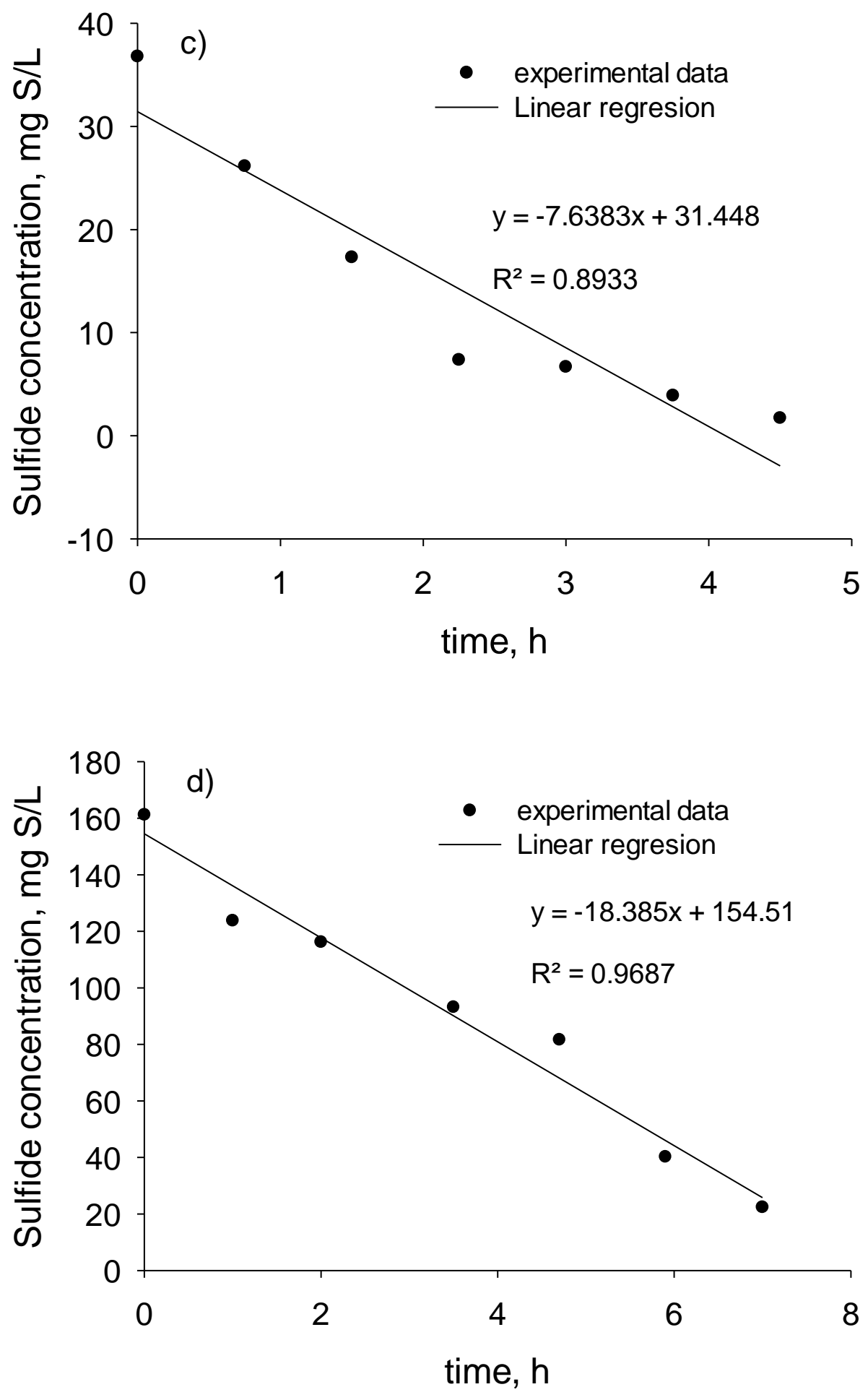


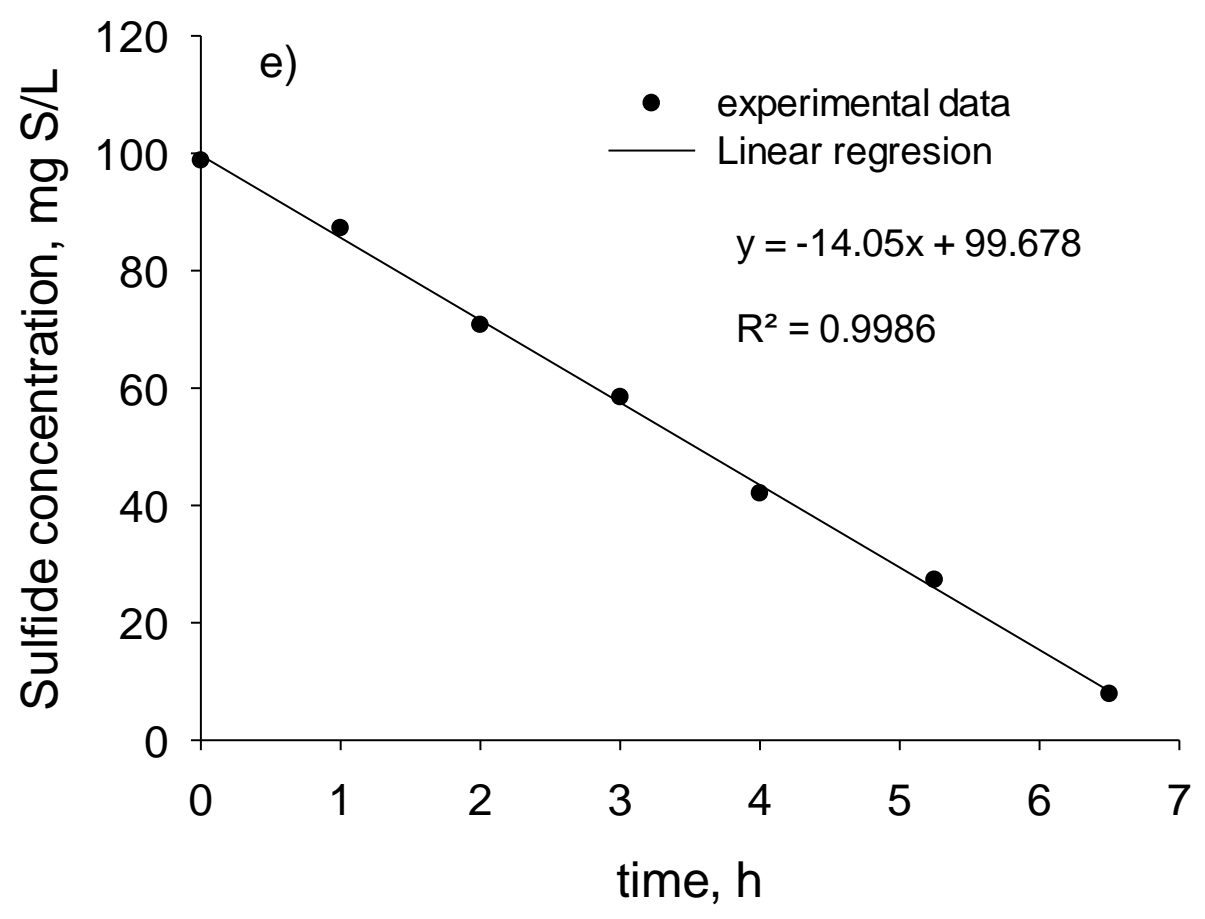

Figure S1: Profiles of H2S-S on the time. a) $\mathrm{H}_{2} \mathrm{~S}-\mathrm{S}=60 \mathrm{mg} \mathrm{S} / \mathrm{L}$; b) $\mathrm{H}_{2} \mathrm{~S}-\mathrm{S}=80 \mathrm{mg} \mathrm{S} / \mathrm{L}$; c) $\mathrm{H}_{2} \mathrm{~S}-\mathrm{S}=40 \mathrm{mg} \mathrm{S} / \mathrm{L} ;$ d) $\mathrm{H}_{2} \mathrm{~S}-\mathrm{S}=160 \mathrm{mg} \mathrm{S} / \mathrm{L} ;$ e) $\mathrm{H}_{2} \mathrm{~S}-\mathrm{S}=100 \mathrm{mg} \mathrm{S} / \mathrm{L}$ 